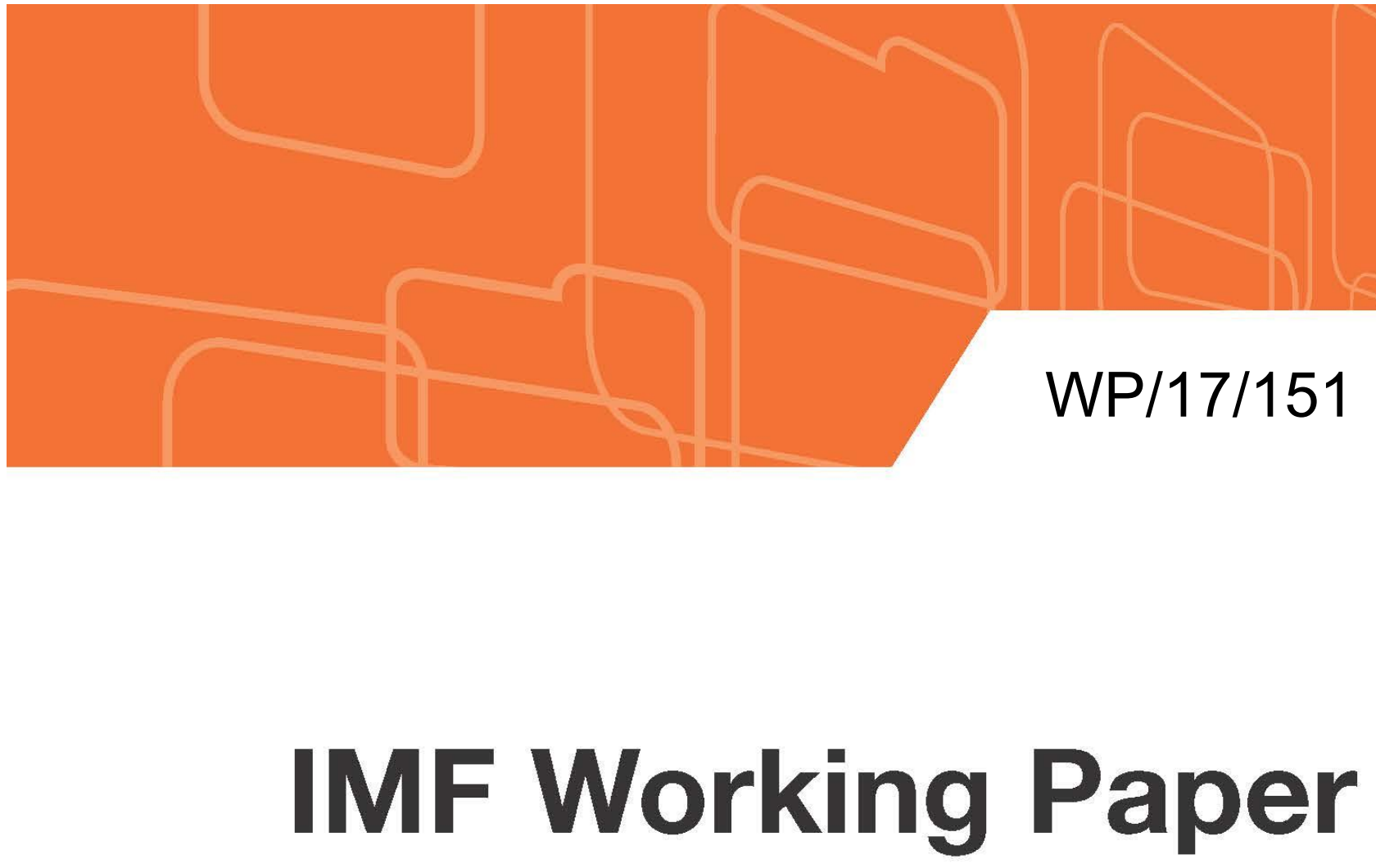

\title{
The Macroeconomic Effects of Trade Tariffs: Revisiting the Lerner Symmetry Result
}

by Jesper Lindé and Andrea Pescatori

IMF Working Papers describe research in progress by the author(s) and are published to elicit comments and to encourage debate. The views expressed in IMF Working Papers are those of the author(s) and do not necessarily represent the views of the IMF, its Executive Board, or IMF management. 


\title{
IMF Working Paper
}

Western Hemisphere Department

The Macroeconomic Effects of Trade Tariffs: Revisiting the Lerner Symmetry Result Prepared by Jesper Lindé and Andrea Pescatori

Authorized for distribution by Nigel Chalk

July 2017

IMF Working Papers describe research in progress by the author(s) and are published to elicit comments and to encourage debate. The views expressed in IMF Working Papers are those of the author(s) and do not necessarily represent the views of the IMF, its Executive Board, or IMF management.

\begin{abstract}
We study the robustness of the Lerner symmetry result in an open economy New Keynesian model with price rigidities. While the Lerner symmetry result of no real effects of a combined import tariff and export subsidy holds up approximately for a number of alternative assumptions, we obtain quantitatively important long-term deviations under complete international asset markets. Direct pass-through of tariffs and subsidies to prices and slow exchange rate adjustment can also generate significant short-term deviations from Lerner. Finally, we quantify the macroeconomic costs of a trade war and find that they can be substantial, with permanently lower income and trade volumes. However, a fully symmetric retaliation to a unilaterally imposed border adjustment tax can prevent any real or nominal effects.
\end{abstract}

JEL Classification Numbers: E52, E58.

Keywords: Import Tariffs; Export Subsidies; Lerner Condition, Incomplete Markets; Complete Markets, Border Adjustment Tax, Trade War, New Keynesian open-economy model.

Author's E-Mail Address: apescatori at imf dot org and jlinde at imf dot org. 


\section{Contents}

1 Introduction $\quad 2$

2 Import and Export Tariffs in a Sticky Price Framework 5

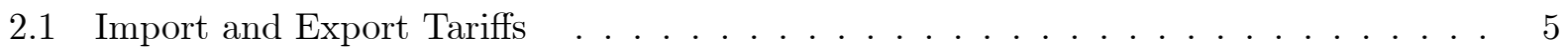

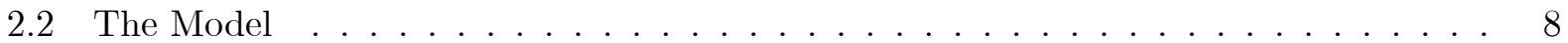

3 The benchmark Case: Lerner Symmetry 10

4 Deviations from Lerner Symmetry 12

4.1 Permanent Deviations: Complete Financial Markets . . . . . . . . . . . . . . . . 13

4.2 Transient Deviations From Lerner Symmetry . . . . . . . . . . . . . . . 16

4.2 .1 Implementation Lags . . . . . . . . . . . . . . . . . . . . . . . . . 16

4.2.2 Gradual Exchange Rate Adjustment . . . . . . . . . . . . . . . . . . . . 17

4.2 .3 Nominal Exchange Rate Pegs . . . . . . . . . . . . . . . . . . . . . . 18

4.2.4 Alternative Price Pass-Through Assumptions . . . . . . . . . . . . . . . 19

5 The Macroeconomic Costs of a Trade War $\quad 21$

5.1 Retaliation through Import Tariffs . . . . . . . . . . . . . . . . . . . . 21

5.2 The Benign Case: A Fully Symmetric Response . . . . . . . . . . . . . . . . . . 23

6 Conclusions 23

$\begin{array}{ll}\text { References } & 25\end{array}$

$\begin{array}{lr}\text { Tables and Figures } & 28\end{array}$

Appendix A The Open Economy New Keynesian Model 34

A.1 Firms and Price Setting . . . . . . . . . . . . . . . . . . 34

A.1.1 Production of Domestic Intermediate Goods . . . . . . . . . . . . . . . . 34

A.1.2 Production of the Domestic Output Index . . . . . . . . . . . . . . . 36

A.1.3 Production of Consumption and Investment Goods . . . . . . . . . . . . . 36

A.2 Households and Wage Setting . . . . . . . . . . . . . . . 38

A.3 Monetary Policy . . . . . . . . . . . . . . . . . . . . . 41

A.4 Fiscal Policy . . . . . . . . . . . . . . . . . . . . . . . . 42

A.5 Resource Constraint and Net Foreign Assets . . . . . . . . . . . . . . . . . 42

A.6 Production of capital services . . . . . . . . . . . . . . . . . . 43

A.7 Solution Method and Calibration . . . . . . . . . . . . . . . . . 44

Appendix B Additional Results $\mathbf{4 5}$

B.1 Effects on Flexible Price-Wage Allocations . . . . . . . . . . . . . . . . 46

B.2 Results Under Producer Currency Pricing . . . . . . . . . . . . . . . . . . . 46

B.3 Results Under Home Currency Invoicing . . . . . . . . . . . . . . . . . . 46

Appendix C Analytical Results under Complete Markets 50

C.1 Model Setup . . . . . . . . . . . . . . . . . . . . . . . 50

C.2 Deterministic Trade Policy . . . . . . . . . . . . . . . . . 50

C.3 Trade Policy Uncertainty _. . . . . . . . . . . . . . . . . . . . . . 51 


\section{Introduction}

The interest in studying the macroeconomic effects of import and export tariffs has grown recently since some recent U.S. tax reform proposals - such as the destination-based-cash-flow tax or its VAT-payroll subsidy equivalent (Auerbach et al., 2017) —implicitly include a border adjustment $\operatorname{tax}(\mathrm{BAT})$ that allows firms to subtract export revenues from their profits but not import costs. ${ }^{1}$ The macroeconomic effects of BATs are currently hotly debated. Detractors have often interpreted the BAT as akin to a protectionist measure while most proponent economists have pointed to the exchange rate as deus ex-machina to contend its macroeconomic neutrality. More generally, as the benefits of globalization are under scrutiny, trade tariffs and their use as tools to protect national economic interests have recently been put at the center of political rhetoric and raised increasing media attention.

Even so, apart from a few recent papers (discussed below), the qualitative and quantitative macroeconomic effects of tariffs and, more specifically BATs, have not been studied at length. In fact, the recent macroeconomic literature has paid little attention to the effects of changes in tariffs in empirically validated macroeconomic models. In particular, it is striking how much of the public and academic debate on the effects of a BAT is still influenced by the long standing Lerner symmetry result in the trade literature. In a seminal paper, Lerner (1936) established the equivalence between import and export tariffs: in a deterministic environment, an import tariff coupled with an export subsidy should lead to a movement in the exchange rate that fully compensates price distortions induced by the trade policy leaving the real equilibrium allocation unaffected (often referred to as the Lerner symmetry theorem). This result has been proved to hold also in more general contexts with multiple goods (see McKinnon, 1966), while Razin and Svensson (1983) and recent work by Erceg, Prestipino and Raffo (2017) show that the change in trade policy must be perceived as permanent for the theorem to hold. However, as major trade and tax reforms occur very infrequently this embedded assumption is seemingly not entirely unrealistic.

In this paper, we re-assess the generality of the Lerner's symmetry result and quantify deviations from symmetry in a medium-scale open economy New Keynesian DSGE model (see Erceg and Linde, 2013). The model assumes that the relocation of production technology is not feasible and that consumers are immobile between countries, two conditions Costinot and Werning (2017)

\footnotetext{
1 Throughout the paper, we will refer to equally-sized import tariffs and export subsidies as a border adjustment tax. Although a BAT may be conceptually different for other purposes, the two concepts are observationally equivalent in our context and we thus use the two terminologies interchangeably.
} 
demonstrated are necessary for the Lerner symmetry result. ${ }^{2}$ We use the model to study the role of alternative firm-pricing behavior, exchange rate determination mechanisms, and asset market assumptions. We also assess a universal BAT adoption and the role of tariff retaliations (trade wars). Differently from Costinot and Werning (2017), our goal is mainly quantitative and we highlight the role of trade policy uncertainty by studying the implications of complete markets.

Under incomplete markets and no portfolio effects, we find that the Lerner's symmetry result is very robust in the long-term since eventually the equilibrium real exchange rate fully offsets the price distortions introduced by the BAT. In the short-term, however, the Lerner's symmetry breaks down when frictions prevent the real exchange rate to fully adjust immediately. It is useful to distinguish between frictions that prevent price adjustment and those that prevent nominal exchange rate adjustment.

Sticky prices (and sticky wages) per se are not a sufficient condition to break the Lerner's symmetry as far as the pass-through from the exchange rate and tariffs to import prices is the same across exporters - and the nominal exchange rate is 'free' to adjust. ${ }^{3}$ In this case, a permanent and unanticipated BAT reform will not have any effect on the real equilibrium regardless of nominal and real rigidities, home bias in investment and/or consumption, or sectorial differences in these rigidities. Hence, dollar-invoicing per se does not break the Lerner's symmetry, in contrast to the arguments in Amiti et al. (2017). ${ }^{4}$

Alternative pricing arrangements that entail heterogeneous pass-through may break the symmetry, however. Specifically, when tariffs are passed on to prices more quickly than exchange rate movements, the exchange rate overshoots and the home country output expands while global trade and output is unaffected. When only import tariffs are passed quickly to prices, the effects are more modest but global trade and output still decline, as exporters increase their margins but cut production in response to lower demand.

Moreover, unless good prices are fully flexible in both countries, the nominal exchange rate determination mechanism will play a key role. The main intuition behind the symmetry result is that the exchange rate response is driven solely by an adjustment in the long-term equilibrium exchange rate. This represents a pure change in expectations that does not require any movement

\footnotetext{
${ }^{2}$ Moreover, we assume that trade is balanced in the steady state. This assumption is innocuous since the existence of trade imbalances per se is neither necessary nor sufficient for the Lerner symmetry result. Similarly, different import or export intensities across industries are neither necessary nor sufficient to break the symmetry, see Costinot and Werning (2017) for further details.

${ }^{3}$ Feenstra (1989) could not reject the null hypothesis that long-run pass-through of tariffs and exchange rates are identical for the Japanese automotive industry.

${ }^{4}$ By dollar invoicing, we mean that tradeable goods are priced in U.S. dollar regardless of their destination.
} 
in cross-country interest rate differentials (and, thus, consumption-saving decisions for the two countries are unaffected). If the trade policy is anticipated, however, the exchange rate strengthens too early leading to an initial decline in home output. The impact is quantitatively minor, though. Gradual adjustment of the exchange rate, on the other hand, induces an sustained expenditure switch towards home products that leads to an increase in home output and drop in output abroad. At the extreme, we show that a nominal currency peg may lead to a significant fall in foreign output and substantial decline in global trade and output in our sticky price framework as foreign monetary policy cannot respond to domestic conditions.

However, neither alternative pricing arrangements nor slow nominal exchange rate adjustment generate deviations from Lerner's symmetry result in the long-term. There is an important exception, though. When international asset markets are complete (i.e., a set of Arrow-Debreu securities contingent on tariffs exist), the symmetry result breaks down. In this case, optimal contracts ensures that the marginal utility from an additional unit of currency is proportional between home and foreign consumers in all states of the world-i.e., the change in the value of consumption expenditure is approximately equated across countries after the BAT shock. Hence, an appreciation of the home currency (e.g., the U.S. dollar) following a BAT shock triggers payoffs from the contingent contracts (i.e., a redistribution) from the United States to the rest of the world, similar to a portfolio effect. This implies that the real exchange rate appreciates by a smaller extent (relative to the BAT rate shock) and cannot fully offset the price distortions induced by the trade policy. ${ }^{5}$ Global trade and output are still unaffected but production shifts to the home country while consumption is shifted abroad. ${ }^{6}$ In terms of magnitudes, the effects are rather large: Under our benchmark calibration which roughly reflects trade flows and relative sizes of the United States and the Euro Area, a home economy (e.g., U.S.) 10 percent BAT shock leads to a one percent increase (drop) in home (foreign) output and two percent decline (rise) in home (foreign) consumption while the real exchange rate appreciates by 6 percent. $^{7}$

Finally, a fully symmetric retaliation that implies an analog boarder adjustment tax in the foreign country is completely neutral. This result is quite robust since it does not rely on exchange rate movements. However, if the retaliation is performed solely through higher import tariffs to offset the export subsidy and match the increase in the tariff in the home economy, then global

\footnotetext{
${ }^{5}$ Notice that payoffs are specified in nominal (not physical) terms. Hence, because purchasing power parity does not hold, asset markets do not imply full consumption insurance.

${ }^{6}$ Dellas and Stockman (1986) and Barari and Lapan (1993) were among the first papers that showed how traditional trade theory results could be overturned under complete international asset markets.

7 We calibrate both the home and foreign economy to match US trade flows with the assumption that trade is balanced in the steady state.
} 
trade and output will be negatively affected. When the model is calibrated to reflect trade flows and relative sizes of the United States and the rest of the world, it implies that a 10 percent rise in import tariffs in both the United States and the rest of the world bloc leads to a 1 percent fall in world trade and 1/2 percent fall in world GDP. A key assumption in this calculation is that the other countries do not increase any tariffs visavi each other; they only impose tarifs visavi the United States. Had they also imposed tariffs visavi each other, the adverse consequences would be notably larger. As an example, when the model is calibrated to reflect the relative sizes of the United States and the Euro area, the same-sized increase in import tariffs leads to a 2 percent fall in trade and 1 percent fall in overall GDP for given degree of openess of the U.S. economy. The larger impact reflects that the degree of openess in the foreign block is effectively larger in this calibration, so import tariffs affects a larger share of consumption and investment goods.

The remaining of the paper is organized as follows. Section 2 discusses how to introduce tariffs in a New Keynesian model and Section 3 the benchmark Lerner's results. In Section 4, we discuss permanent and transient deviations from the symmetry result to various perturbations of the model. The macroeconomic costs of trade wars are discussed in Section 5. Finally, Section 6 concludes.

\section{Import and Export Tariffs in a Sticky Price Framework}

In this section, we describe how we introduce custom duties (i.e., import and export tariffs) in a sticky price framework under either producer or local currency pricing. We also describe the fiscal implications and define the relevant terms of trade. We then offer a brief overview of the workhorse two-country New Keynesian model we use in the simulations. Further details on the model can be found in Appendix A.

\subsection{Import and Export Tariffs}

The home economy imports (exports) bundles of goods and services used for both consumption and investment purposes from (to) the foreign economy (foreign economy's variables are marked with an $\left.{ }^{*}\right)$. All goods are tradable but home bias in preferences favors domestic over foreign produced goods.

Under flexible import prices, the law-of-one-price (gross of custom duties) holds ${ }^{8}$

$$
P_{M, t}=S_{t} P_{X, t}^{*} \frac{1+\tau_{M, t}}{1+\tau_{X, t}^{*}}
$$

8 The arbitrage condition behind the law-of-one-price holds for producers since consumers are assumed to be immobile across countries. 
where $P_{M, t}$ is the final import price index in domestic currency, $S_{t}$ is the nominal exchange rate (home per foreign currency), $P_{X, t}^{*}=P_{D, t}^{*}$ is export price index which is equal to the price index of foreign domestically produced goods, $P_{D, t}^{*}$, (both expressed in foreign currency), $\tau_{M, t}$ is the uniform import tariff levied by the home economy, and $\tau_{X, t}^{*}$ is a uniform export subsidy (or tax if negative) levied by the foreign economy. ${ }^{9}$ An equation analog to (1) holds for the foreign economy. Movements in the exchange rate and foreign prices as well as in custom duties, $\tau_{M, t}$ and $\tau_{X, t}^{*}$, are free to fully and immediately affect import prices.

Two alternative pricing assumptions are usually adopted in the open-economy literature as source of nominal rigidities: producer currency pricing (PCP henceforth) and local currency pricing (LCP henceforth). ${ }^{10}$

LCP assumes pricing to market and invoicing in local currency reflecting firms' price-setting behavior where markets are segmented and export prices are possibly rigid in the currency of the export market (see e.g. Betts and Devereux, 2000, and Devereux and Engel, 2003). In this environment changes in custom duties as well as exchange rate will only gradually transmit to the price of imported goods and services. Let $\delta_{t}$ denote the percent deviations from the law of one price for the home economy, it follows from equation (1) that $\delta_{t}$ can be written as

$$
\delta_{t} \simeq-p_{M, t}+s_{t}+p_{X, t}^{*}+\tau_{M, t}-\tau_{X, t}^{*}
$$

in first differences we have (where $\pi_{t}=\Delta p_{t}$ )

$$
\begin{aligned}
\Delta \delta_{t} & =-\pi_{M, t}+\Delta s_{t}+\pi_{X, t}^{*}+\Delta \tau_{M, t}-\Delta \tau_{X, t}^{*} . \\
\Delta \delta_{t}^{*} & =-\pi_{M, t}^{*}-\Delta s_{t}+\pi_{X, t}+\Delta \tau_{M, t}^{*}-\Delta \tau_{X, t} .
\end{aligned}
$$

Import price inflation, $\pi_{M, t}$, is, in turn, determined by import price Phillip's curve

$$
\pi_{M, t}=\frac{\beta}{1+\iota_{M}} \mathrm{E}_{t} \pi_{M, t+1}+\frac{\iota_{M}}{1+\iota_{M}} \pi_{M, t-1}+\kappa_{M}\left(m c_{t}^{*}+\delta_{t}\right)
$$

where $m c_{t}^{*}$ denotes (steady state log-deviations of) real marginal costs in the foreign economy, $\iota_{M}$ is indexation to past inflation among the non re-setting firms, and $\beta$ the discount factor. Equation (5) implies that import prices only adjusts gradually to changes in import tariffs, at a speed determined by $\kappa_{M}=\left(1-\xi_{M}\right)\left(1-\beta \xi_{M}\right) / \xi_{M}$ where $\xi_{M}$ is the probability that an import firm is not allowed

\footnotetext{
${ }^{9}$ Throughout the paper we define the exchange rate as how many units of the domestic currency is required to purchase one unit of the foreign currency. Hence, a reduction in the exchange rate means an appreciation of the home currency.

${ }^{10}$ Distribution costs are often introduce to account for a high pass-through from exchange rate to import prices but a low pass-through from import prices to consumer prices (Burstein, Eichenbaum, and Rebelo 2006 and Corsetti et al 2005). Our main qualitative results, however, are not affected by an explicit introduction of a distribution sector.
} 
to re-set its price. Notice that even if prices are flexible in the import sector (so $\kappa_{M}$ is arbitrarily large), we can still have deviations from the law of one price $\left(\delta_{t}\right.$ differs from nil) as flexible import prices only ensures that $m c_{t}^{*}+\delta_{t}=0$-i.e., since we have LCP (i.e., market segmentation), different degrees of price stickiness between the home and foreign market induce a deviation from the lawof-one-price (LOP).

Under PCP export prices are set (and are sticky) in the domestic currency of the exporter such that the price in the home country of a foreign good moves one-for-one with changes in the nominal exchange rate (Obstefeld and Rogoff 2000, Corsetti and Pesenti 1998 INCLUDE). Because markets are assumed to be perfectly integrated, the law of one price holds at all times, $P_{X, t}^{*}=P_{D, t}^{*}$. Hence, under PCP equation (1) holds ${ }^{11}$

$$
\pi_{M, t}=\Delta s_{t}+\pi_{D, t}^{*}+\Delta \tau_{M, t}-\Delta \tau_{X, t}^{*}
$$

Notice that PCP does not imply that import prices are fully flexible, as export price inflation $\pi_{D, t}^{*}$ may respond only gradually to foreign real marginal costs $m c_{t}^{*}$. To impose fully flexible import prices, we need to impose the additional assumption of full flexibility of domestic prices, so $m c_{t}^{*}=0 .{ }^{12}$ Even so, it is clear from eq. (6) that the effects on $\pi_{M, t}$ of import tariffs are substantially more front-loaded under PCP.

As there is strong empirical support for LCP (for example Engle and Rogers 2001), however, we will maintain this framework as benchmark throughout the paper, but note that the main aspects of our results are invariant to the LCP assumption. To show this, we report results in Appendix B for PCP. We will discuss those results together with our baseline results in Section 3. An analog discussion holds for the foreign economy.

It is useful to define the terms of trade as the ratio of import to export prices net of import tariffs.

$$
\operatorname{ToT}_{t}=\frac{1+\tau_{M, t}^{*}}{1+\tau_{M, t}} \frac{P_{M, t}}{S_{t} P_{M, t}^{*}},
$$

where $P_{M, t} /\left(1+\tau_{M, t}\right)$ is the price paid (by the home country) for imports and $S_{t} P_{M, t}^{*} /\left(1+\tau_{M, t}^{*}\right)$ is the price charged (by the home country) for its exports (expressed in home currency). When the LOP holds we have $T o T_{t}=\frac{1+\tau_{M, t}^{*}}{1+\tau_{M, t}} \frac{P_{M, t}}{S_{t} P_{M, t}^{*}}=\frac{P_{M, t}}{P_{X, t}} \frac{1+\tau_{X, t}}{1+\tau_{M, t}}$.

\footnotetext{
${ }^{11}$ Equivalently, PCP implies replacing equation (5) with $\Delta \delta_{t}=0$ which, combined with equation (3), gives equation (6)

12 Note that this implies that PCP holds in the flex price-wage version of the model.
} 
If the pass-through from tariffs to prices is low, ceteris paribus, the terms of trade appreciates after a tariff shock. Vice versa, if the USD appreciates but export prices are sticky in foreign currency then the terms of trade depreciates. When the exchange rate does not fully offset an increase in the tariff the term of trade appreciates. ${ }^{13}$

Our definition of the terms of trade in eq. (7) allows us to express the trade balance as function of the terms of trade

$$
T B_{t} / P_{t} Y_{t}=\frac{S_{t} P_{M, t}^{*} / P_{t}}{1+\tau_{M, t}^{*}} X_{t}-\frac{P_{M, t} / P_{t}}{1+\tau_{M, t}} M_{t}=\frac{P_{M, t} / P_{t}}{1+\tau_{M, t}}\left[T o T_{t}^{-1} X_{t} / Y_{t}-M_{t} / Y_{t}\right]
$$

Notice that import tariffs (but not export subsidies) introduce a wedge between home (foreign) import expenditure and foreign (home) exporter revenues which has to be taken into account in the calculation of the trade balance.

It is also easy to see the fiscal implication of custom duties as the home government custom revenues are given by

$$
\tau_{M, t} \frac{P_{M, t}}{1+\tau_{M, t}} M_{t}-\tau_{X, t} \frac{S_{t} P_{M, t}^{*}}{1+\tau_{M, t}^{*}} X_{t} .
$$

It is worth noting that in a log-linear approximation around a steady state where trade is balanced and tariffs are zero implies that there are no first-order effects from BATs to public finances (i.e., there is a symmetric and opposite effect from equally-sized import tariff and export subsidy on government revenues and expenses). ${ }^{14}$

Finally, we should point out that in our model that we will describe next, both goods intended for consumption and investment purposes are traded, but since the degree of stickiness is assumed to be the same in both sectors, and the tariffs and subsidies are levied on both goods we did not distinguish between them in the exposition above.

\subsection{The Model}

The model we use is a large-scale two country/region model with endogenous investment and labor supply decision that closely follows Erceg, Guerrieri and Gust (2006) and Erceg and Linde (2013). Each region is assumed to be equally large and the parameterizations of the model is completely symmetric. Abstracting from open economy features, the specification of each country block builds

\footnotetext{
13 As Obstfeld and Rogoff (2000) noted, a sticky price framework in which imports are invoiced in the importing country's currency (LCP) implies that, keeping trade tariffs constant, unexpected currency appreciations are associated with deteriorations of the terms of trade contrary to what happens under PCP.

${ }^{14}$ The (log-linear) trade balance as share of GDP is given by $t b_{t}=-\bar{x} \overline{t o t}_{t}+x_{t}-m_{t}$, where $x$ and $m$ are export and import share of GDP (where the bar denotes the steady state) while $\widetilde{t o t}$ is the terms of trade in deviation from 1 .
} 
heavily on the estimated models of Christiano, Eichenbaum and Evans (CEE, 2005) and Smets and Wouters $(2003,2007)$. Thus, the model includes both sticky nominal wages and prices and indexation; habit persistence in consumption; investment (rather than the capital) adjustment costs, and a financial accelerator. The model departs from this earlier literature, however, by assuming that some fraction of households are "Keynesian," and simply consume their current after-tax income in a hand-to-mouth fashion. ${ }^{15}$

On the open economy dimension, the benchmark model assumes local currency pricing, as previously described, while financial markets are incomplete as only a single "internationally traded" bond available is available. The exchange rate is, thus, determined by the choice of foreign and domestic bond holding, which in our model boils down to a uncovered interest rate parity (UIP, henceforth) condition where net foreign assets enters to ensure stationarity of bond holdings. We will study deviations from then UIP in Section 4.2. The trade share of the home economy is set to 14 percent of its GDP, roughly matching the U.S. trade share. This pins down the trade intensity of both consumption and investment for the home country under the additional assumption that the import intensity of consumption is equal to $3 / 4$ of investment. For symmetry reasons, we also assume that the home economy is equally sized as the foreign economy. Our balanced trade assumption then imply an equally sized trade share of the foreign economy. This calibration is suitable for studying the impact of tariffs and subsidies on trade and output for U.S. and the Euro Area, which are about equally sized currency unions, although it overstates the extent of trade between the United States and the Euro Area. Therefore, in the section on trade wars (Section 5), we also discuss the economic effects when entertaining a United States versus the rest of the world calibration of the model (which features the same trade intensity, but assumes that United States only accounts for 23 percent of the world economy). As the assumption is that tariffs and subsidies are only imposed between (and not within) the two blocks, this calibration is more reasonable to trace out the global effects of a U.S. BAT reform if foreign countries solely retaliates versus the United States and not towards any other country.

In the benchmark model, monetary policy is assumed to follow a Taylor-style rule where the central bank reacts to domestic inflation, $\pi_{t}$, and the flex-price output gap $x_{t}$ :

$$
i_{t}=\gamma_{i} i_{t-1}+\left(1-\gamma_{i}\right)\left[\pi_{t}+\psi_{p}\left(\pi_{t}-\bar{\pi}\right)+\psi_{x} x_{t}+\psi_{\Delta x} \Delta x_{t}\right]
$$

Importantly, the central bank does not react to exchange rate movements directly (in section 4 we

\footnotetext{
15 Galí, López-Salido and Vallés (2007) show that the inclusion of non-Ricardian households helps account for structural VAR evidence indicating that private consumption rises in response to higher government spending.
} 
will later study nominal exchange rate pegs).

Government spending evolves exogenously. To satisfy intertemporal fiscal balance, a lump-sum tax paid by optimizing households adjust gradually to both government debt and the change in government debt. Further details on the model and how it is calibrated and solved is provided in Appendix A.

\section{The benchmark Case: Lerner Symmetry}

Figure 1 reports the responses to (i) a permanent 10 percent hike in the home import tariff $\tau_{M t}$ (see eqs. 2 - 5; dotted red line); (ii) a permanent 10 percent hike in the home export subsidy $\tau_{X, t}$ (dashed blue line); and (iii) their combined effects (i.e., the border adjustment tax: home import tariff $\tau_{M, t}$ and export subsidy $\tau_{X, t}$ move simultaneously; black solid line).

The hike in import tariffs appreciates the home (real and nominal) exchange rate (panel 9 and 10) as the domestic policy rate and the interest rate differential increase (panel 11 and 12). ${ }^{16}$ Home real imports falls (panel 6) while the home terms of trade appreciates (i.e., falls; panel 8) with a delayed peak due to the LCP assumption. The terms of trade appreciation, in turn, induces a positive wealth effect on consumption but a drag on real net export (Panel 5 and 6) that implies a decline in output. The appreciation of the terms of trade is, however, sufficient to improve the nominal trade balance (panel 7). The expenditure switch to domestic products from imported consumption goods (panel 3) occurs because the import tariff hike in the home country outweighs the appreciated exchange rate, so prices of imported goods rise somewhat for home consumers. However, for foreign households, consumption of imported goods (panel 4) is eventually cut by over 10 percent as import prices gradually rises due to the depreciated exchange rate. Regarding spillovers on foreign economic activity, we see from panel 2 that the adverse spillovers to foreign output are relatively muted and transient, as the depreciated terms of trade boost foreign real net exports. Finally, in the flex price-wage equilibrium of our model, reported in Appendix B.1, domestic output declines with -0.5 percent on impact since the immediate transmission of the appreciated real exchange rate cause net real exports to fall sharply on impact. Similarly, foreign output rise on impact in the flex price-wage equilibrium because their real net exports rise sharply.

Figure 1 also documents that a 10 percent hike in the export subsidy has completely opposite effects to those for the import tariff except for the nominal and real exchange rates (panels 9 and

\footnotetext{
${ }^{16}$ The exchange rate appreciates although the policy differential falls because of the permanent nature of the shock. So one cannot use the UIP condition in eq. (11) to imply that the home exchange rate must depreciate due to a negative policy rate differential path since such a calculation incorrectly assumes that $\lim _{j->\infty} \mathrm{E}_{t} s_{+j}=0$.
} 
10), which appreciates slightly less than in the import tariff case. The relatively smaller exchange rate appreciation - both in real and nominal terms - is explained by the real and nominal policy rate differentials (panel 12) which is mostly driven by the central bank reaction to inflation.

Under incomplete markets, the relation between the exchange rate and interest rates is governed by the (log-linear) UIP condition

$$
i_{t}-i_{t}^{*}=\Delta \mathrm{E}_{t} s_{t+1}-\phi_{b} b_{f, t}
$$

where the net foreign assets as share of GDP, $b_{f, t}$, ensures stationarity of foreign bond holdings when $\phi_{b}>0$ (a positive value for $b_{f, t}$ implies that the domestic economy has a net claim on the rest of the world). ${ }^{17}$ Neglecting net foreign assets $b_{f, t}$, we can solve forward equation (11)

$$
s_{t}=-\sum_{j=0}^{\infty} \mathrm{E}_{t}\left(i_{t+j}-i_{t+j}^{*}\right)+\bar{s}_{t}
$$

where $\bar{s}_{t}=\lim _{j->\infty} \mathrm{E}_{t} s_{t+j}$ is the long-term (expected) equilibrium exchange rate. ${ }^{18}$ Changes in the nominal value of the currency can thus be determined by the equilibrium exchange rate solely without having to rely on movements in current or expected interest rate differentials.

After the export subsidy shock, about one-third of the smaller nominal exchange rate appreciation is explained by the forward sum of the interest rate differential which is negative instead of positive as in the import tariff case (Panel 12), while about two thirds of the larger exchange rate appreciation is explained by the equilibrium exchange rate $\bar{s}_{t}$.

The combined effects of the import tariff and export subsidy shock exactly cancel out-i.e., the Lerner symmetry holds for a permanent and unanticipated introduction of a BAT (solid black line in Figure 1). The only variables that are affected by the BAT are the real and nominal exchange rate, which both immediately appreciate for the home economy by the same magnitude as the tariff and subsidy (i.e. by 10 percent). Intuitively, the exchange rate appreciation hits two birds with a stone offsetting both the effects of the import tariff (by effectively lowering the pre-tariff import price of the home economy by 10 percent) and the export subsidy (by increasing the effective export price by 10 percent). And because the changes in the tariff and subsidy are permanent and unexpected, the appreciated exchange rate can offset them with a one-time level jump.

\footnotetext{
17 To ensure the stationarity of foreign asset positions, we follow Turnovsky (1985) by assuming that domestic households must pay a transaction cost when trading in the foreign bond. Our results are not at affected by our choice of $\phi_{b}$ within an empirically realistic range for it. See Appendix A for further details.

${ }^{18}$ Notice that an analog equation holds in real terms $e_{t}=-\sum_{j=0}^{\infty} \mathrm{E}_{t}\left(r_{t+j}-r_{t+j}^{*}\right)+\bar{e}_{t}$, where $e$ and $r$ are the real exchange and interest rate.
} 
Formally, by inspecting equations (3) and (4) it is easy to see how $\Delta s_{t}=\Delta \tau_{M, t}=\Delta \tau_{X, t}$ perfectly offsets both the import tariff and export subsidy while the UIP, equation (12), allows the exchange rate to adjust instantaneously without having to alter households' consumption-saving decisions. So neither $P_{M, t}$ nor $P_{M, t}^{*}$ need to adjust. It is worth mentioning, however, that home consumers are wealthier in the sense that the dollar-value of their relative consumption expenditure, $P C /\left(e P^{*} C^{*}\right)$, has increased (see section 4.4 for a discussion).

The Lerner symmetry theorem holds even if there are asymmetries in the degree of price stickiness in the home import and export sectors or across countries. It would also be easy to show that the introduction of additional sectors (for example, a flexible price sector) would not alter the result.

Another interesting case is when all traded goods are invoiced in the home currency (e.g., in US dollars). Amiti, Itskhoki and Konings (2017) argues that this would break Lerner symmetry. We can examine this case within our model by assuming LCP in the home import sector (so that foreign exporters set their prices in the home currency) and PCP in the foreign import sector. In Appendix B.3 we show that the Lerner theorem still holds, although the effects of the individual instruments $\left(\tau_{M, t}\right.$ and $\left.\tau_{X, t}\right)$ differ relative to the benchmark calibration with LCP (i.e. invoicing in the currency of the importing country). The reason why Lerner still holds, is that the pass-through from the exchange rate and tariffs to prices is the same across exporters. Moreover, amending the model with variable markups following Gust, Leduc and Sheets (2009) mitigates the effects of each individual instruments $\left(\tau_{M, t}\right.$ and $\left.\tau_{X, t}\right)$ somewhat, but Lerner still holds up.

In the next sections we will explore other price setting assumptions and exchange rate determination mechanisms that make the model depart from the symmetry result.

\section{Deviations from Lerner Symmetry}

In this section, we examine a number of mechanisms which breaks the Lerner symmetry result. We focus on the role of exchange rate adjustment and some alternative pricing assumptions that causes symmetry to fail. Alternative exchange rate assumptions which causes deviations from symmetry includes international complete assets markets, gradual nominal exchange rate adjustment, nominal exchange rate pegs, and if the trade reform is implemented with delay. We organize the discussion of these mechanisms into channels which generate permanent and temporary deviations. Furthermore, uncertainty whether the tariffs will remain in place infinitively will also break the Lerner symmetry. But since this mechanism is discussed in detail by Erceg, Prestipino and Raffo (2017), we omit it 
in our exposition below.

\subsection{Permanent Deviations: Complete Financial Markets}

Complete international financial markets allow households to trade assets that have payoffs specific to each possible state of the world giving households the possibility to insure against country specific shocks. In particular, it is now possible to insure against trade policy uncertainty by buying and selling financial assets that are contingent to tariffs.

Since markets are segmented (i.e., home and foreign consumers face different prices for the same good) we assume that it is impossible to make state-contingent trades that allow payoffs in physical goods, instead payoffs are specified in nominal terms. In that case, optimal contracts ensures that the marginal utility from an additional unit of currency, $\Lambda_{C, t} / P_{t}$, is proportional between home and foreign consumers in all states ${ }^{19}$

$$
Q_{t}=\Lambda_{C, t}^{*} / \Lambda_{C, t}
$$

where $Q_{t}=S_{t} P_{C, t}^{*} / P_{C, t}$ is the real exchange rate. The complete markets condition (13) differs fundamentally from the incomplete markets condition. To see this, first notice that the UIP equation (11) can be rewritten in real terms as

$$
i_{t}-\mathrm{E}_{t} \pi_{C, t+1}-\left(i_{t}^{*}-\mathrm{E}_{t} \pi_{C, t+1}^{*}\right)=\Delta \mathrm{E}_{t} q_{t+1}-\phi_{b} b_{f, t}
$$

where $\Delta q_{t}$ is given by $\Delta s_{t}+\pi_{C, t}^{*}-\pi_{C, t}$. Linearizing the Euler equations for consumption

$$
\Lambda_{C, t}=\beta \mathrm{E}_{t} \frac{\left(1+i_{t}\right)}{1+\pi_{C, t+1}} \Lambda_{C, t+1}, \Lambda_{C, t}^{*}=\beta \mathrm{E}_{t} \frac{\left(1+i_{t}^{*}\right)}{1+\pi_{C, t+1}^{*}} \Lambda_{C, t+1}^{*},
$$

and substituting them into the previous equation, we finally derive

$$
\Delta \mathrm{E}_{t} q_{t+1}-\phi_{b} b_{f, t}=\Delta \mathrm{E}_{t} \lambda_{C, t+1}^{*}-\Delta \mathrm{E}_{t} \lambda_{C, t+1}
$$

where $\lambda_{C, t}=d \Lambda_{C, t} / \Lambda_{C}$ and $\lambda_{C, t}^{*}=d \Lambda_{C, t}^{*} / \Lambda_{C}^{*}$. The complete markets condition (eq. 13), on the other hand, implies that

$$
\Delta q_{t}=\Delta \lambda_{C, t}^{*}-\Delta \lambda_{C, t}
$$

As previously discussed, Lerner symmetry requires exchange rate movements to occur without altering households' consumption and saving decisions. This is feasible under incomplete markets because eq. (15) only holds in expectations; hence, any permanent and unanticipated movement in

\footnotetext{
${ }^{19}$ Without loss of generality we have assumed a the constant of proportionality equal to 1.
} 
the exchange rate is not sufficient to violate eq. (15). Under complete markets, instead, eq. (15) (abstracting from $b_{f, t}$ ) has to hold for all shock realizations which means that any movement in the exchange rate triggers a relative change in household consumption and saving behavior. As a consequence, the Lerner symmetry will not hold.

To gain further insights, it is also useful to strip down the model to a simpler version with log utility of consumption, no habit persistence, equal sales taxes, and no 'hand to mouth' consumers. Under these simplifying assumptions, the complete markets condition of eq. (13) simplifies to

$$
S_{t} P_{C, t}^{*} C_{t}^{*}=P_{C, t} C_{t}
$$

In this case, optimal contracts ensure that the dollar value of home and foreign consumption expenditures are equated. And the exchange rate movement leads to a transfer of resources across countries akin to a balance sheet's valuation effect. For example, assuming that prices are initially fully rigid, if the nominal exchange rate appreciates by $x$ percent home to foreign consumption volume ratio will fall by $x$ percent. ${ }^{20}$ The fact that household consumption-saving decisions will have to change under complete markets whereas they may not under incomplete markets might be surprising, since the complete markets assumption is supposedly a more efficient arrangement. However, as Stockman (1989) and Barari and Lapan (1993) point out, the welfare superiority of complete markets holds only under efficient shocks but not for distortionary shocks such as the ones studied here. Indeed, since contracts' payoffs are nominal (e.g., in US dollars rather than in consumption units), foreign households want to insure against a loss of the value of their own currency (vis a vis the home currency) while home consumers want to insure against higher consumption prices induced by the tariff; hence, a full insurance arrangement where consumption volumes are equated is not an equilibrium. As our workhorse model does not allow us to demonstrate the breakdown from Lerner equivalence under complete markets analytically, we use a simple static model in Appendix C - which builds on the framework in Dellas and Stockman (1986) - to demonstrate that uncertainty about trade policy causes deviations from the equilvalence result under complete markets. Under perfect foresight (i.e. no uncertainty about trade policies), the appendix shows that the symmetry result holds up even under complete markets.

The impact of a BAT shock is considerable under complete markets (Figure 2). Initially, output contracts notably in the domestic economy (Panel 1) and expands in the foreign economy (Panel

\footnotetext{
${ }^{20}$ Notice that this result is not specific to the sticky price allocations. In the flex-price-wage notional equilibrium, the appreciation of the home real exchange rate will cause the real consumption ratio to rise (e.g. foreign consumption to rise and domestic consumption to fall). This is discussed in detail by Dellas and Stockman (1986).
} 
2) before the impact on domestic output becomes positive and the benign effects on the foreign economy are reversed. Consistent with the model in Dellas and Stockman (1986), the effects on domestic (foreign) consumption (Panels 5 and 6) are unambiguously negative (positive), reflecting the associated real exchange rate appreciation of the domestic currency (Panel 12).

To examine the role of the two instruments behind the overall result, Figure 3 teases out their partial effects of the import tariff and export subsidy shocks. The import tariff $\tau_{M t}$ shock has rather transient effects on actual and potential output, whereas the export subsidy $\tau_{X, t}$ has much more persistent positive effect on home output. Since the responses are symmetric in the foreign economy, this means that the foreign economy expands temporarily following the hike in the foreign export subsidy whereas it contracts persistently following the hike in home import tariff (Panel 1 and 3$)$.

World output contracts following an increase in the import tariff and expands by an identical amount for an increase in the export subsidy $\tau_{X, t}$ (Panel 4). In fact, the partial effect on world output is identical for the two instruments under both complete and incomplete markets. So the presence of asset markets only affects the split-up of the production between the domestic and foreign economy for each instrument. World output is, thus, unchanged when considering the combined effects of both trade policy instruments.

We now turn to discuss the composition of GDP. In the home economy, the output expansion in the medium and longer term is mainly driven by net exports (Panel 7) and is modestly supported by a slight rise in investment (not shown) while the fall in private consumption is only a partial offset. The home-to-foreign consumption ratio drops by about 4 percent which explains most of the movement in the real exchange rate (of about -5 percent, Panel 12) since nominal rigidities imply a slow movement in the inflation differential (Panel 11). If prices were less sticky, the consumption differential would nevertheless remain roughly the same, but the larger initial decline in the inflation differential would cause a larger initial appreciation of the nominal exchange rate and a smaller fall in output. In fact, the initial decline in home output is caused by price rigidities (compare black lines in Panel 1 and 3); if prices were fully flexible, home (foreign) output would rise (fall) immediately and not be subject to sign reversal over time.

Finally, we briefly discuss the implications for trade. Home real net exports rise by an identical amount after a BAT shock (Panel 7). However, because the domestic terms of trade depreciates (Panel 8) notably following the export subsidy $\tau_{X, t}$ hike, the domestic nominal trade balance as share of GDP, shown in Panel 9, does not improve for export subsidy. The trade balance only 
improves for the import tariff $\tau_{M, t}$ because for this shock the domestic terms of trade appreciates notably, especially in the near-term. In Panel 10, we report the implications for World trade as share of GDP. World trade flows rise following a hike in $\tau_{X, t}$ but falls following a hike in $\tau_{M, t}$. This may seem inconsistent with the fact that net exports rise equally much for both tax instruments (Panel 7), but it is explained by the fact that the improvement in net exports following the tariff hike is driven by a decline in imports as opposed to the rise in export which follows after the hike in $\tau_{X, t}$. Even so, as was the case under incomplete markets, there are no effects on World trade after the combined shock of both $\tau_{M . t}$ and $\tau_{X, t}$.

\subsection{Transient Deviations From Lerner Symmetry}

In this section, we discuss mechanisms which generate transient, yet sometimes substantial, deviations from Lerner symmetry.

\subsubsection{Implementation Lags}

First, we repeat the previous exercise but assuming that the BAT shock is announced 4 quarters before it is actually implemented. ${ }^{21}$ Figure 2 (green dash-dotted line) shows that the deviations from Lerner symmetry due to implementation lags are modest (Figure 2, green dash-dotted line). The real and nominal exchange rates jump on announcement of the trade policy reform, but since the actual implementation is delayed 4 quarters, exports fall and imports rise somewhat, resulting in a peak decline in domestic output of about 0.2 percent after two years. There are no long-term effects on neither home nor foreign output. Moreover, it is important to note that World GDP (i.e., the weighted sum of home and foreign output per capita reported in Panels 1 and 2 in the figure) remains unchanged even in the short term. So even if implementation lags cause some short-term deviations from Lerner symmetry, it is a zero sum game at the global level.

Although not shown, we have also computed the effects of a 2 quarter delay between announcement and implementation, which should perhaps be viewed as a bit more realistic from empirical perspective. In this latter case, the peak decline in GDP is less than 0.1 percent. Therefore, the model suggest that even short-term deviations from Lerner symmetry stemming from implementation lags should be modest.

\footnotetext{
21 Major trade and tax reforms are usually known in advance to a large share of the public-both firms and households - before they are actually implemented.
} 


\subsubsection{Gradual Exchange Rate Adjustment}

As noted previously, the results in the benchmark model is contingent on an immediate sizeable appreciation of the nominal and real exchange rates. The UIP condition embedded into the model facilitates this exchange rate adjustment. There is, however, strong empirical evidence against the standard UIP condition. VAR evidence suggests that the impulse response function for the real exchange rate after a shock to monetary policy is hump-shaped with a peak effect after about 1 year (see, e.g., Eichenbaum and Evans, 1995; Faust and Rogers, 2003), whereas the standard UIP condition imply a peak effect within the quarter followed by a relatively quick mean reversion. Moreover, a DSGE model with a standard UIP condition cannot account for the so-called 'forward premium puzzle' recorded in the data (i.e., a currency whose interest rate is high tends to appreciate which implies that the risk premium must be negatively correlated with the expected exchange rate depreciation, see, e.g., Fama, 1984; Froot and Frankel, 1989, and Duarte and Stockman, 2005). In an attempt to account for these empirical shortcomings, we modify the UIP condition to allow for a negative correlation between the risk premium and the expected change in the exchange rate, following the vast empirical evidence reported in, for example, Engel (1996).

Our modified UIP condition is, thus, given by

$$
i_{t}-i_{t}^{*}=\left(1-\phi_{s}\right) \mathrm{E}_{t} s_{t+1}-\phi_{s} s_{t-1}-\phi_{b} b_{f, t}
$$

The suggested modification of the risk premium introduces a lagged dependence between the nominal exchange rate and the domestic interest rate (which is absent in the standard UIP condition, see eq. 11). Adolfson et al. (2008) documents that this alternative formulation, with $\phi_{s}$ estimated to be about 0.6 , helps their model to account for the hump-shaped impulse response function of the real exchange rate to a monetary policy shock found in VARs. It also improves the forecasting properties of the RER. We set $\phi_{s}=0.6$, following Adolfson et al. (2008) and refer to this case as "Gradual Exchange Rate Adjustment" since the modified UIP condition (18) only alters the pace by which the real exchange rate appreciation occurs.

Even under the gradual exchange rate adjustment deviations from Lerner symmetry are fairly modest (Figure 2, the red dotted line). With slower appreciation of the home real and nominal exchange rate, domestic output expands by 0.3 percent after 2-3 years before receding to baseline (no change) after 5 years. The slower appreciation of the exchange rate boosts the home trade balance by over 1 percent of GDP (Panel 7) during the first year, roughly as much as the domestic terms of trade (Panel 8) appreciates nearly 10 percent initially before receding to back to nil when 
the exchange rate adjust. Panel 9 shows that it takes about 3 years for the home real exchange rate to appreciate 10 percent whereas it takes the nominal exchange rate (Panel 10) about 5 years to appreciate by 10 percent.

In conclusion, relatively to the case of implementation lags, gradual exchange rate adjustment implies a greater deviation from Lerner symmetry. Even so, it only results in short-term deviations without any effect on global trade and GDP.

\subsubsection{Nominal Exchange Rate Pegs}

We now consider the effects of a nominal exchange rate peg. To begin with, we assume that the foreign economy is pegging its nominal exchange rate vis a vis the domestic economy. So the foreign nominal interest rate rule now takes the following simple rule (see equation 10 or equation A.26 in Appendix A):

$$
i_{t}^{*}=-\gamma_{s} \Delta S_{t}
$$

where $\gamma_{s}$ is set arbitrarily large. ${ }^{22}$

If prices were fully flexible, a nominal exchange rate peg would not matter for equilibrium allocations as the real exchange rate adjustment is brought about by movements in relative prices. However, when the exchange rate peg is coupled with nominal rigidities the real exchange rate adjustment takes much longer leading to a deviation from Lerner symmetry (Figure 2 blue dashed line). In addition, Figure 2 shows that the even world GDP goes down considerably in the short term because both domestic and, especially, foreign output per capita fall.

The inability of the foreign monetary authority to react to domestic conditions exacerbates the impact of the BAT shock on the foreign economy since the home central bank cuts the policy rate at a measured pace because there is only a modest fall in home CPI inflation and output (Figure 4 blue dashed line, Panels 9-12 ). This cut in the nominal interest rate is not enough to achieve price stability in foreign economy, and foreign inflation falls significantly. This implies a substantial rise in the foreign real rate of interest which triggers foreign consumption and output to contract with about -5 percent. Lower foreign consumption and investment are the key drivers behind the fall in foreign output whereas higher foreign net exports attenuate the decline only modestly (Panels 5 and 6). In the home country, instead, the net export drag more than offset slightly higher domestic demand and induces a (modest) decline in home output.

\footnotetext{
${ }^{22}$ As a higher (lower) value of $S$ means an appreciated (depreciated) currency from the perspective of the foreign economy, we have a minus sign in front of $\gamma_{s}$ to indicate that the policy rate will be lowered (raised) sufficiently to offset any movements in $S_{t}$ in equilibrium.
} 
For completeness Figure 4 (red dotted line) shows the responses to BAT shock for the hypothetical case when the home economy is pegging its nominal exchange rate to the foreign economy. In this case, the foreign economy is assumed to follow the Taylor rule (eq. A.26) and be able to react to domestic conditions whereas the home economy follows the rule

$$
i_{t}=\gamma_{s} \Delta S_{t}
$$

where $\gamma_{s}$ is set arbitrarily large. As can be seen from the figure, the effects are completely symmetric but flipped; in this case the real exchange rate appreciation occurs gradually via higher home prices and the home economy experiences a sharp boom in economic activity due to the lower real rates (and associated rise in consumption and investment) despite a slight worsening of home real net exports through higher real imports.

\subsubsection{Alternative Price Pass-Through Assumptions}

In this section, we study alternative assumptions about pass-through of the tariffs and subsidies onto prices. We will make two alternative assumptions: 1) Export firms fully pass both import tariffs and export subsidy $\tau_{M, t}$ and $\tau_{X, t}$ fully into import prices; 2) Foreign export firms fully pass only import tariffs $\tau_{M, t}$ to import prices, but home export firms does not, implying that the export subsidy pass-through remains unchanged and determined by eq. (4) and the foreign equivalent of eq. (5). ${ }^{23}$

In this first case, the deviations from the law of one price (eq. 2) is modified to

$$
\delta_{t}=-p_{M, t}+s_{t}+p_{X, t}^{*}
$$

The price Phillips curve (eq. 5) is unchanged expressed as a pre-tariff price but the actual import price inflation is

$$
\pi_{M, t}^{A c t}=\pi_{M, t}+\Delta \tau_{M, t}-\Delta \tau_{X, t}^{*}
$$

where now $\pi_{M, t}$ is the home import price net of tariffs and subsidies charged by the foreign exporters. This way to think about tariffs closely resembles a U.S. style sales tax. Similar equations hold in the foreign country such that

$$
\pi_{M, t}^{*, A c t}=\pi_{M, t}^{*}+\Delta \tau_{M, t}^{*}-\Delta \tau_{X, t}
$$

\footnotetext{
23 The home exporters pricing equation is given by $\pi_{M, t}^{*}=\frac{\beta^{*}}{1+\iota_{M}^{*}} \mathrm{E}_{t} \pi_{M, t+1}^{*}+\frac{\iota_{M}^{*}}{1+\iota_{M}^{*}} \pi_{M, t-1}^{*}+\kappa_{M}^{*}\left(m c_{t}+\delta_{t}^{*}\right)$ where we assume that $\beta^{*}=\beta, \iota_{M}^{*}=\iota_{M}$, and $\kappa_{M}^{*}=\kappa_{M}$. See Appendix A for further details.
} 
In Figure 5, the blue dashed line report the effects of a combined rise in $\tau_{M, t}$ and $\tau_{X, t}$ under this alternative pass-through assumption. ${ }^{24}$ As can be seen from Panels 9 and 10 in the figure, home (foreign) CPI inflation jumps (plummet) with almost 5 percent in the first period, reflecting the immediate pass-through. A little more than 1 percentage points of the annualized CPI inflation in the first period partly reflects an increase in domestic inflation, because imported inflation only contributes by 4 p.p. for a 10 percent import tariff hike $\left(\Delta \tau_{M}\right)$ when the assumed importconsumption trade share is about 10 percent, $\Delta \tau_{M} \times 4 \times M / C=4$ p.p.. The slight rise in overall CPI inflation in the following periods reflects that economic activity (Panel 1) in the home economy rises persistently (recalling that domestic potential output is unchanged since Lerner symmetry holds in the flex-price economy), so that higher inflation on domestically produced goods outweigh the deflationary pressures from lower import prices (not shown) due the appreciated nominal exchange (Panel 6) rate which gradually transmits into lower import prices according to eqs. (21) and (5). The home real exchange rate (Panel 5) appreciates even more than 10 percent in the near term, reflecting that foreign (domestic) prices jumps down (up). But over time, the gap between the actual and potential real exchange rate closes as the effects of slow price adjustment dissipates.

Because the central banks are assumed to react to one-period ahead inflation they see through the short-run inflation dynamics. Even so, the home central bank still hike the nominal policy rate with almost 1 percent after a year due to the positive effects on home growth and output gap (Panel 1) and the rise in CPI inflation. The foreign central bank, however, cuts the policy rate with the exact same amount (see Panels 11 and 12) due to the deflationary pressure on CPI inflation (Panel 10) stemming from the negative growth and output gap (Panel 2) impact from the combined home tariff and subsidy (in the foreign economy, the deflationary pressure on domestic inflation outweighs the positive contribution on $\pi_{M, t}^{*, A c t}$ from imported inflation $\pi_{M, t}^{*}$ in eq. 23 stemming from its depreciated nominal exchange rate).

Even though the Lerner symmetry breaks down, there are no effects on World GDP and trade neither in the near or long term. In fact, despite the rise in home real net exports which contributes to the boom in the home economy, World trade does not change because the rise in home export is exactly offset by lower home import (Panel 3, 4, and 7).

In the second case, instead, World trade fall, leading to an initial fall also in World output

\footnotetext{
${ }^{24}$ All other features of the experiment are exactly as in Figure 1, apart from the fact that the domestic and foreign central banks in this experiment is assumed to react to expected rather than actual CPI inflation $\mathrm{E}_{t} \pi_{C, t+1}$ so that they do not hike/cut interest rates massively in response to the short-lived impetus of $\tau_{M, t}$ and $\tau_{X, t}$.
} 
(Figure 5, red dotted line). The slower pass-through for the export subsidy mitigates the immediate fall in foreign CPI inflation (Panel 10), while now home exports fall (instead of rising) because of lower foreign demand and slower home export price adjustment. Because home real exports do not rise whereas foreign exports fall sharply due to the quick influence of $\tau_{M, t}$, World trade (Panel 7) falls over $1 / 2$ percent in the near term, and because home output expands less than foreign output declines, World GDP falls somewhat initially before subsequently expanding as can be seen in Panel 8. Monetary policy plays an important role for subsequent expansion in World GDP as the foreign $\mathrm{CB}$ cuts policy rates more than the home CB hike rates (the interest rate differential shown in Panel 12 is more than twice as elevated as the hike in the home policy rate shown in Panel 11) due to the persistent downward pressure on foreign CPI inflation rate this causes foreign output to contract somewhat less than output in the domestic economy expands.

\section{The Macroeconomic Costs of a Trade War}

In this section, we examine the effects of a "Trade War", which we assume play out in two different incarnations. First, we assume the foreign economy retaliates to a BAT by imposing only an import tariff equal to the sum of the import and export subsidy (i.e., $\tau_{M, t}^{*}=\tau_{X, t}+\tau_{M, t}=20$ percent in our exercise). This retaliation scheme will ensure that the tariff-subsidy differentials $\tau_{M . t}-\tau_{X, t}^{*}$ and $\tau_{M . t}^{*}-\tau_{X, t}$ in eqs. (3) and (4) rise equally much; in our experiment 10 percent each. Second, we consider a case when the foreign economy retaliates in a fully symmetric way by imposing both a foreign import tariff equal to the home export subsidy (i.e. $\tau_{M, t}^{*}=\tau_{X, t}$ ) and an export subsidy equal to the home import tariff (i.e. $\tau_{X, t}^{*}=\tau_{M, t}$ ) - for example, both countries impose the same BAT. We will refer to this case as "symmetric retaliation", although it does not necessarily imply imposing the same tariff (subsidy) in the home economy as abroad, it is symmetric only in sense that in ensures that the tariff-subsidy differentials $\tau_{M . t}-\tau_{X, t}^{*}$ and $\tau_{M . t}^{*}-\tau_{X, t}$ remain unchanged.

\subsection{Retaliation through Import Tariffs}

Figure 6 report the effects of the foreign economy retaliation through import tariffs under incomplete markets (IM, blue dashed line) and complete markets (CM, red dotted line).

The CM assumption implies that the effects on the home and foreign quantities and prices are completely symmetric and the nominal exchange rate remains unaffected. However, the home terms of trade worsens by 10 percent as the foreign tariff $\tau_{M, t}^{*}$ is hiked with 10 percent more than the 
domestic tariff $\tau_{M, t}$. This implies that the home trade balance as share of nominal GDP deteriorates permanently - by roughly -1.4 percent (i.e., the terms of trade deprecation times the steady state import share of output, which equals 0.14). Since the trade deficit is assumed to be financed by lump sum transfers by unconstrained households, it does not have any real effects in the model.

In contrast, the impact under IM feature non-symmetric results on allocations. Since home and foreign economy is effectively imposing the same increase in net-tariffs $\tau_{M . t}-\tau_{X, t}^{*}$ and $\tau_{M, t}^{*}-\tau_{X, t}$ (see eqs. 3 and 4), the non-symmetric effect on home and foreign output shown in Figure 6 may be surprising at first glance. However, the non-symmetric effects can be explained by the fact that the import tariffs $\left(\tau_{M, t}\right.$ and $\left.\tau_{M, t}^{*}\right)$ have a direct effect on the terms of trade (see eq. 7 ) and thereby on the nominal trade balance as share of GDP (eq. 8). In our example, $\tau_{M, t}^{*}$ is increased by 20 percent whereas $\tau_{M, t}$ is only increased by 10 percent. This has a direct depreciative effect on the home terms of trade with 10 percent, but since the relatively larger hike in the foreign import tariff causes the home nominal exchange rate to depreciate about 5 percent (panel 10), the depreciation of the home terms of trade totals 15 percent (panel 9). ${ }^{25}$

Another way of thinking about the asymmetric responses under incomplete markets is to use the Lerner symmetry results in Figure 1 . Since Lerner's symmetry holds for $\tau_{M . t}$ and $\tau_{X . t}$, the retaliation experiment is isomorphic to a 20 percent hike in the foreign import tariff $\tau_{M, t}^{*}$. Hence, except for the home nominal exchange rate, the IM responses of Figure 6 effectively show the partial impact of a permanent 20 percent hike in the foreign import tariff. From this perspective, the overall non-symmetric effects are not surprising.

Moreover, retaining a CM or IM assumption does not matter for the global effects of the trade war (panels 11 and 12). The incomplete and complete asset markets assumption just affects how the costs are split between the home and foreign economies (when the size of the two countries is the same). At a global level, the costs are substantial, global deteriorates permanently with nearly 1 percent and global trade declines with 2 percent of baseline GDP. Furthermore, it should be noted that the invariance of global trade and GDP to the asset market assumption is not contingent on both economies being of equal size. When the domestic economy is assumed be only 23 percent of the world economy, that is we think about the home economy as the United States and the foreign economy as the rest of the world, global trade and GDP still fall equally much under incomplete and complete asset markets albeit half as little as in Figure 6 (i.e. with 1 and $1 / 2$ percent, respectively).

\footnotetext{
${ }^{25}$ In other words, the retaliation experiment just studied is not analog to a change in $\tau_{M}$ and $\tau_{M, t}^{*}$ with 10 percent each. Such a change would have had completely symmetric effects on economic activity in the domestic and foreign economies without any changes in the exchange rate and terms of trade.
} 
These results are qualitatively similar to the tariff scenario presented in IMF (2016).

\subsection{The Benign Case: A Fully Symmetric Response}

Finally, we analyze the case when the foreign economy responds by providing export subsidies to their exporters to match the hike in home tariffs and raising the import tariff to just offset the home export subsidy (i.e., $\tau_{M}=-\tau_{X}^{*}$ and $\tau_{M}^{*}=-\tau_{X}$ ).

A fully symmetric response nullifies the adverse impact of a trade war regardless of how exchange rates are determined (Figure 6 black line). In addition, if trade is balanced, the budgetary implications of a combined import tariff and export subsidy are only of second order.

Thus, there is a 'bad' and 'good' way for foreign economies to respond to trade reform in the home economy. The bad way involves slapping an import tariff large enough to offsetting the home export subsidy and matching the hike in the home import tariff. The good way involves the foreign government using both import tariffs and export subsidies to mimic adjustment in home tariffs and subsidies. This neutrality result, however, breaks down under the second of our alternative pricing assumptions analyzed in Section 4.4.

\section{Conclusions}

We have quantified the macroeconomic effects of tariffs and of border adjustment taxes (BATs) in an empirically validated New Keynesian open-economy model under various firm-pricing behavior assumptions, exchange rate determination mechanisms, and asset market assumptions.

Under incomplete markets, we find support for the Lerner equivalence between an import tariff and an export subsidy in the long run. In the short-term, however, the Lerner's symmetry breaks down when various frictions such as implementation lags or gradual nominal exchange rate adjustment prevent the real exchange rate to adjust fully immediately. Deviations are relatively modest, however, and in both cases there is no effect on global trade and output. Exchange rate pegs, however, lead to a substantial fall in foreign and, thus, global output in our sticky price framework.

Importantly, sticky prices (and sticky wages) or local-currency pricing per se are not a sufficient condition to break the Lerner's symmetry. Hence, dollar-invoicing per se does not break the Lerner's symmetry. However, when tariffs are passed to prices more quickly than exchange rate movements, the exchange rate overshoots and the home country output expands while global trade and output is unaffected. To discriminate among the various hypotheses we have made would require either an 
explicit micro-fundation of exporters' price setting behavior or empirical evidence on the symmetry between tariffs and exchange rate pass-through to import prices.

The paper also shows the importance of international asset markets. In fact, under complete markets, the symmetry result breaks down in both the short and long run. Since optimal contracts ensure that the shadow value of home and foreign currencies is equated across states, an appreciation of the home currency (e.g., the US dollar) triggers payments from the US to the rest of the world, like a portfolio effect (i.e., when the US dollar appreciates the value of foreign assets held by US investors decline and viceversa). This implies that the real exchange rate appreciates by a smaller extent (relative to the incomplete market case) and, thus, it is not able to fully offset the price distortions induced by the trade policy. Global trade and output are still unaffected but production is shifted to the home country while consumption is shifted to the foreign country. The effects are quantitatively important.

Finally, we also assessed the macroeconomic costs of trade wars. A fully symmetric retaliation that implies an analog boarder adjustment tax in the foreign country is completely neutral. This result is quite robust since it does not rely on exchange rate movements. On the other hand, if the foreign countries retaliates exclusively through higher import tariffs, then global trade and output will be adversely affected. The effects are quantitatively relevant. For a calibration aimed at capturing the trade flows and relative sizes of the United States and the rest of the world, our model implies that a 10 percent effective increase in import tariffs between - but not inside - both regions leads to a 1 percent fall in world trade and 1/2 percent fall in world GDP.

In future work, it would be interesting to consider the impact of the zero lower bound on the results and to estimate the effects of import and export tariffs using empirical methods, to see if the model implications are borne out by the data. In addition, we have throughout the paper retained the assumptions that trade is balanced and no tariffs are in place in the steady state trade. As a consequence, there are no fiscal implications from the boarder adjustment tax. Also, in the case of incomplete markets we assume no balance sheet effects from exchange rate movements. It would be interesting to explore the implications of relaxing these assumptions. Furthermore, as our analysis have demonstrated that the macroeconomic effects of trade tariffs and subsidies are highly contingent on the functioning of international asset markets, the empirical merits of the incomplete and complete markets assumption deserves further attention. Rabanal and Tuesta (2010) and Chari, Kehoe and McGrattan (2000) find some evidence in favor of incomplete markets, but it is by no means a clear cut and the issue is not the focus of their studies. 


\section{References}

Adolfson, Malin, Stefan Laséen, Jesper Lindé and Mattias Villani (2005), "The Role of Sticky Prices in an Open Economy DSGE Model: A Bayesian Investigation", Journal of the European Economic Association Papers and Proceedings 3(2-3), 444-457.

Adolfson, Malin Stefan Laséen, Jesper Lindé and Mattias Villani (2008), "Evaluating an estimated new Keynesian small open economy model," Journal of Economic Dynamics and Control 32(8), 2690-2721.

Altig, David, Christiano, Lawrence J., Eichenbaum, Martin and Jesper Lindé (2011), "Firm-Specific Capital, Nominal Rigidities and the Business Cycle", Review of Economic Dynamics 14(2), 225-247.

Amiti, Mary, Oleg Itskhoki and Jozef Konings (2017), "Why the Proposed Border Tax Adjustment Is Unlikely to Promote U.S. Exports," Liberty Street Economics Blog, February 24.

Ascari, Guido and Tiziano Ropele (2007), "Optimal Monetary Policy Under Low Trend Inflation," Journal of Monetary Economics 54, 2568-2583

Auerbach, Alan, Michael P. Devereux, Michael Keen and John Vella (2017), "Destination-Based Cash Flow Taxation", Oxford University Centre for Business Taxation Working Paper No. 17-01.

Barari, Mahua and Harvey E. Lapan (1993), "Stochastic trade policy with asset markets : The role of tariff structure," Journal of International Economics 35(3-4), 317-333.

Betts, Caroline and Michael B. Devereux (2000), "Exchange rate dynamics in a model of pricingto-market," Journal of International Economics 50(1), 215-244.

Bernanke, Ben, Gertler, Mark and Simon Gilchrist (1999), "The Financial Accelerator in a Quantitative Business Cycle Framework", in John B. Taylor and Michael Woodford (Eds.), Handbook of Macroeconomics, North-Holland Elsevier Science, New York.

Burstein, Ariel, Martin Eichenbaum, and Sergio Rebelo (2005). "Large devaluations and the real exchange rate." Journal of political Economy 113(4): 742-784.

Chari, V. V Patrick J. Kehoe, Ellen R. McGrattan (2002), "Can Sticky Price Models Generate Volatile and Persistent Real Exchange Rates?," Review of Economic Studies 69(3): 533-563

Christiano, Lawrence J., Martin Eichenbaum and Charles Evans (2005), "Nominal Rigidities and the Dynamic Effects of a Shock to Monetary Policy", Journal of Political Economy 113(1), $1-45$.

Christiano, Lawrence J., Mathias Trabandt and Karl Walentin (2007), "Introducing financial frictions and unemployment into a small open economy model," Sveriges Riksbank Working Paper Series No. 214.

Corsetti, Giancarlo, and Luca Dedola. "A macroeconomic model of international price discrimination." Journal of International Economics 67.1 (2005): 129-155.

Corsetti, Giancarlo, and Paolo Pesenti. "Welfare and Macroeconomic Interdependence." Quarterly Journal of Economics, vol. 116, no. 2, 2001, pp. 421-445.

Dellas, Harris and Stockman, Alan C. Stockman (1986), "Asset markets, tariffs, and political risk," Journal of International Economics 21(3-4), 199-213.

Devereux, Michael B. and Charles Engel (2003), "Monetary Policy in the Open Economy Revisited: Price Setting and Exchange-Rate Flexibility," Review of Economic Studies 70(4), 765-783.

Dixit, Avinash K, and Joseph E. Stiglitz (1977), "Monopolistic Competition and Optimum Product Diversity", American Economic Review 67(3), 297-308. 
Duarte, Margarida and Alan C. Stockman (2005), "Rational Speculation and Exchange Rates", Journal of Monetary Economics 52, 3-29.

Eichenbaum, Martin and Charles L. Evans (1995), "Some Empirical Evidence on the Effects of Shocks to Monetary Policy on Exchange Rates," Quarterly Journal of Economics 110, 9751010 .

Engel, Charles (1996), "The Forward Discount Anomaly and the Risk Premium: A Survey of Recent Evidence", Journal of Empirical Finance 3, 123-192.

Engel, Charles, and John H. Rogers (2001). "Violating the Law of One Price: Should we make a Federal Case Out of it?" Journal of Money, Credit, and Banking 33(1), 1-15.

Erceg, Christopher, Guerrieri, Luca and Christopher Gust (2006), "SIGMA: A New Open Economy Model for Policy Analysis", Journal of International Central Banking 2(1), 1-50.

Erceg, Christopher and Jesper Lindé (2013). "Fiscal Consolidation in a Currency Union: Spending Cuts vs. Tax Hikes", Journal of Economic Dynamics and Control, 37, 422-445.

Erceg, Christopher and Jesper Lindé (2014), "Is There A Fiscal Free Lunch In a Liquidity Trap?", Journal of the European Economic Association 12(1), 73-107.

Erceg, Christopher, Pristipino, Andrea and Andrea Raffo (2017), "The Macroeconomic Effects of Trade Policies", Manuscript, Federal Reserve Board, Washington, DC.

Fama, Eugene (1984), "Forward and Spot Exchange Rates", Journal of Monetary Economics 14, $319-338$

Faust, Jon and John Rogers (2003), "Monetary Policy's Role in Exchange Rate Behavior", Journal of Monetary Economics 50, 1403-1424.

Feenstra, Robert C. "Symmetric pass-through of tariffs and exchange rates under imperfect competition: An empirical test." Journal of international Economics 27.1-2 (1989): 25-45.

Froot, Kenneth. and Jeffery Frankel (1989), "Forward Discount Bias: Is It an Exchange Risk Premium", Quarterly Journal of Economics 104(1), 139-61.

Galí, Jordi and Mark (1999), "Inflation Dynamics: A Structural Econometric Analysis", Journal of Monetary Economics, 44, 195-220.

Galí, Jordi, Gertler, Mark and David López-Salido (2001), "European Inflation Dynamics", European Economic Review, 45, 1237-70.

Gust, Christopher J., Sylvain Leduc, and D. Nathan Sheets (2009). "The Adjustment of Global External Balances: Does Partial Exchange-Rate Pass-through Matter?," Journal of International Economics 79(2), 173-185.

IMF (2016), "Subdued Demand Symptoms and Remedies", World Economic Outlook, Chapter 1, October 2016.

Juillard, Michel (1996), "Dynare : A Program for the Resolution and Simulation of Dynamic Models with Forward Variables Through the Use of a Relaxation Algorithm," CEPREMAP Working Paper 9602.

Lerner, Abba P. (1936), "The Symmetry Between Import and Export Taxes," Economica 3(11), 306-313.

Lindé, Jesper (2005), "Estimating New Keynesian Phillips Curves: A Full Information Maximum Likelihood Approach", Journal of Monetary Economics, 52(6), 1135-49.

McKinnon, Ronald I. (1966), "Intermediate Products and Differential Tariffs: A Generalization of Lerner's Symmetry Theorem," Quarterly Journal of Economics 80(4), 584-615. 
Obstfeld, Maurice, and Kenneth Rogoff. "New directions for stochastic open economy models." Journal of international economics 50.1 (2000): 117-153.

Rabanal, Pau, and Vicente Tuesta. "Euro-dollar real exchange rate dynamics in an estimated twocountry model: An assessment." Journal of Economic Dynamics and Control 34.4 (2010): 780-797.

Razin, Assaf and Lars E.O. Svensson (1983), "The Terms of Trade and the Current Account: The Harberger-Laursen-Metzler Effect," Journal of Political Economy 91(1), 97-125.

Smets, Frank and Raf Wouters (2003), "An Estimated Stochastic Dynamic General Equilibrium Model of the Euro Area", Journal of the European Economic Association 1(5), 1123-1175.

Smets, Frank and Raf Wouters (2007), "Shocks and Frictions in US Business Cycles: A Bayesian DSGE Approach", American Economic Review 97(3), 586-606.

Turnovsky, Stephen J. (1985), "Domestic and foreign disturbances in an optimizing model of exchange-rate determination." Journal of International Money and Finance 4(1): 151-171. 
Figure 2: Deviations from Lerner Symmetry for Import Tariffs and Export Subsidies.

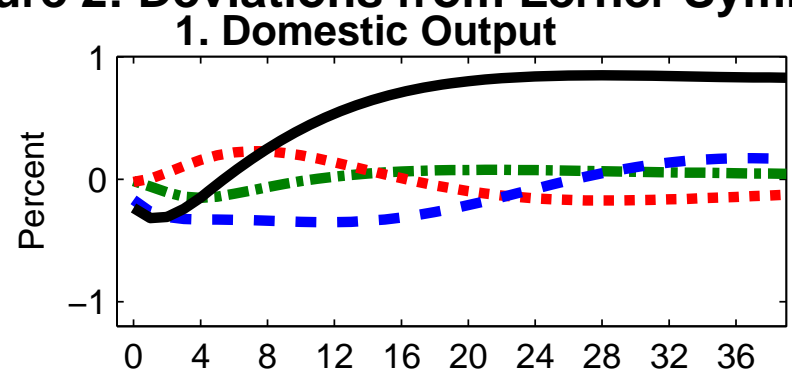

2. Foreign Output

3. Domestic Consumption

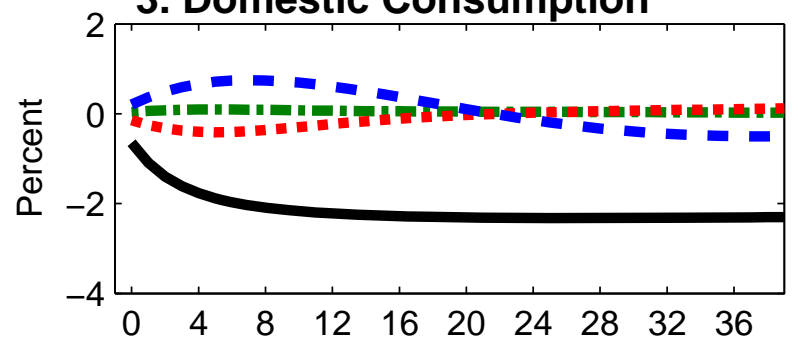

5. Domestic Real Exports

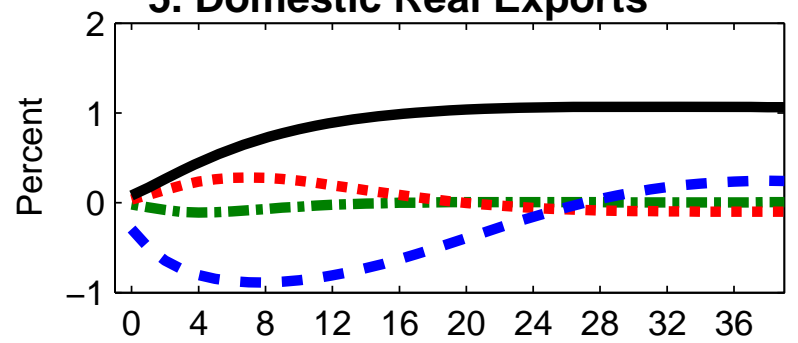

7. Domestic Nominal Trade Balance

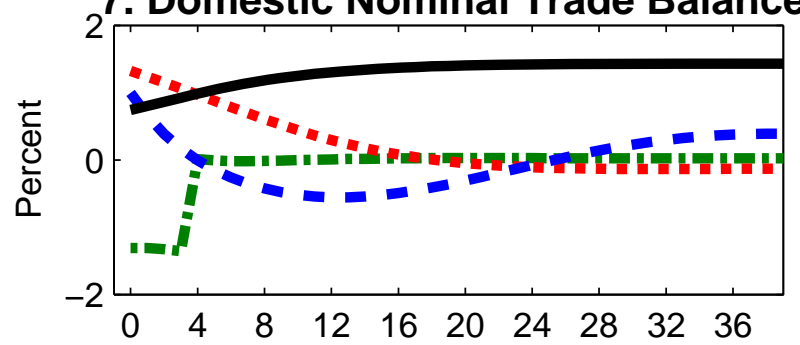

9. Domestic Real Exchange Rate
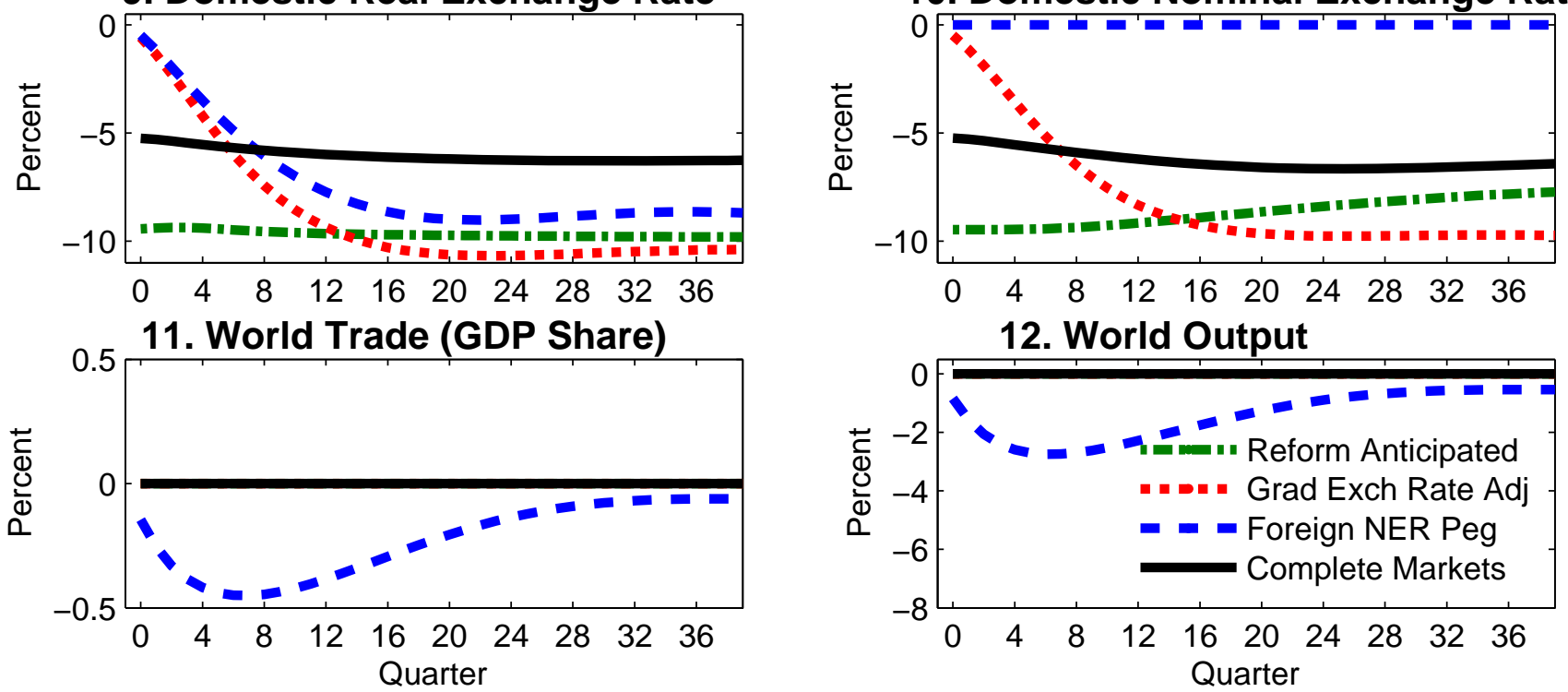
Figure 3: Permanent Import Tariffs and Export Subsidies Under Complete Markets.

1. Domestic Output

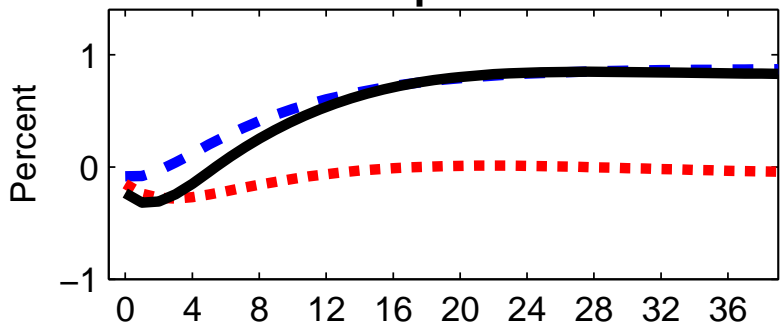

3. Domestic Potential Output

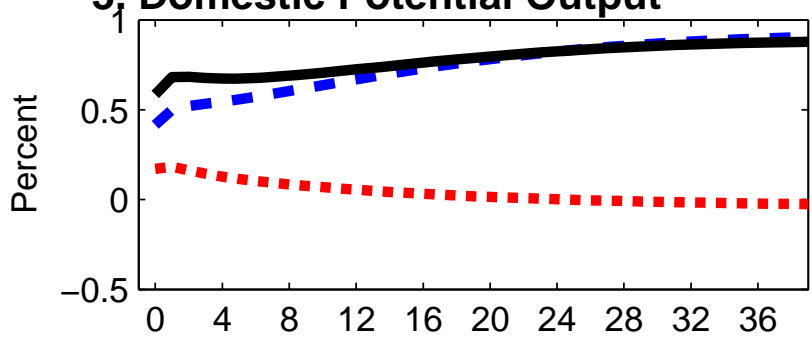

5 . Domestic Consumption

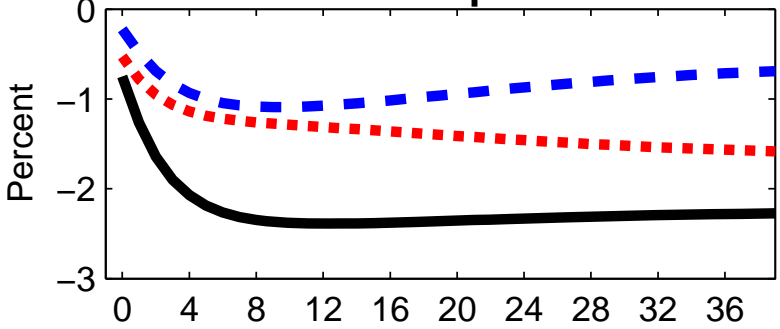

7. Domestic Real Net Exports (GDP share)

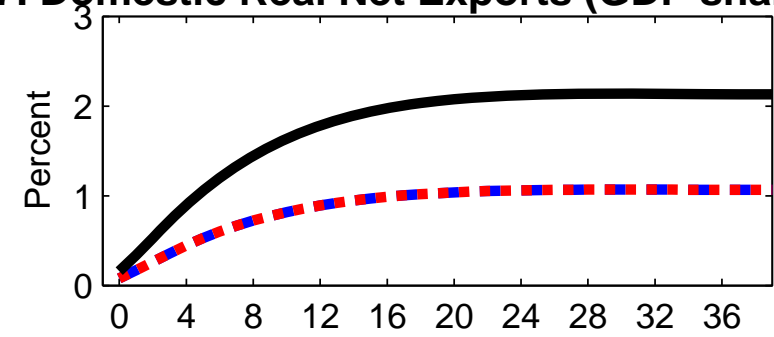

2. Foreign Output
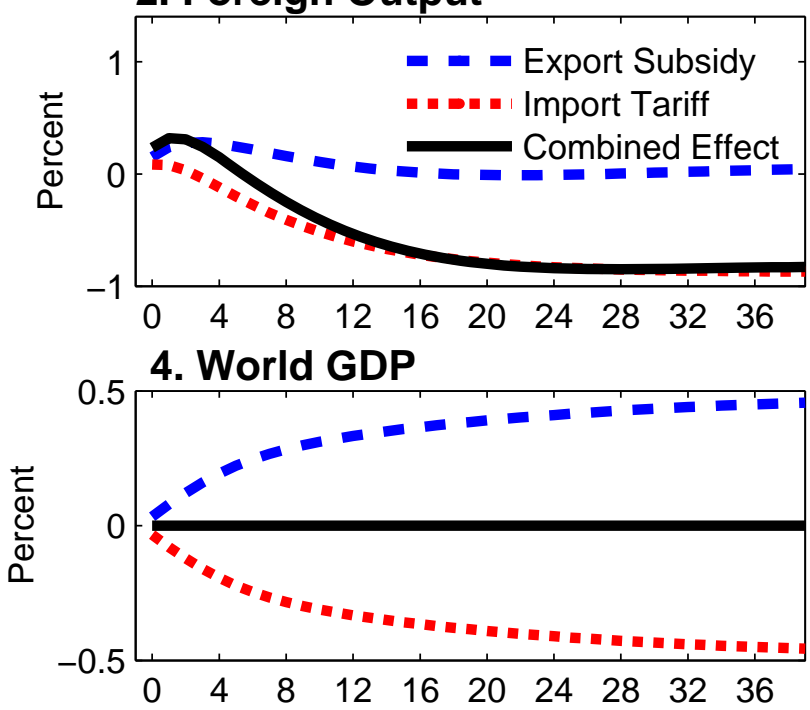

6. Foreign Consumption

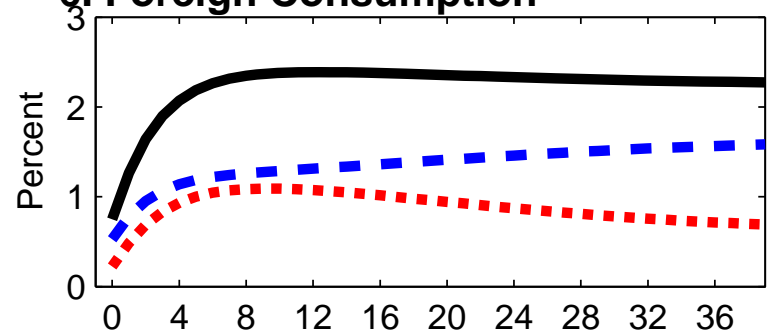

8. Domestic Terms of Trade

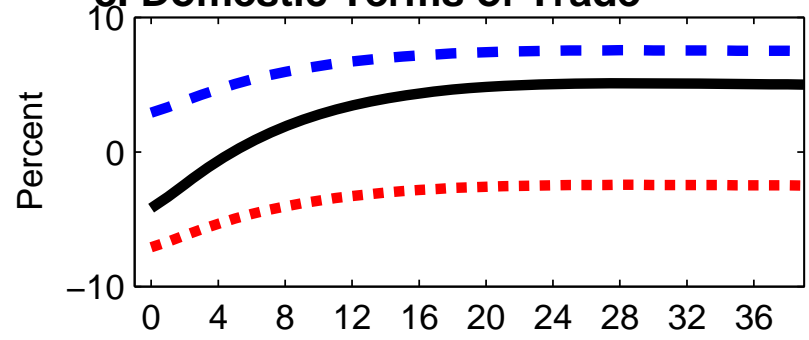

9. Domestic Nominal Trade Balance (GDP share) 10. World Trade (GDP share)

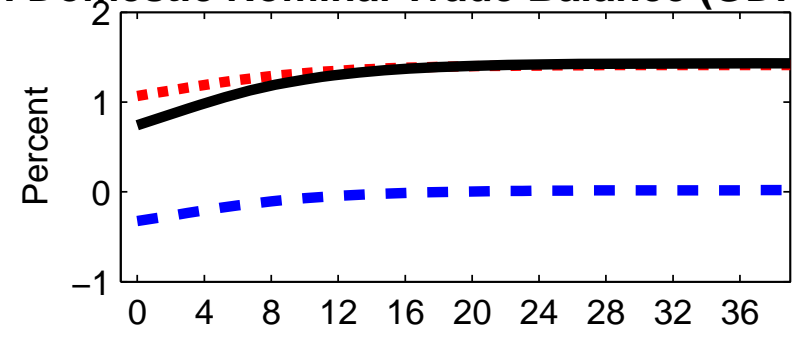

11. Domestic-Foreign Price Differential

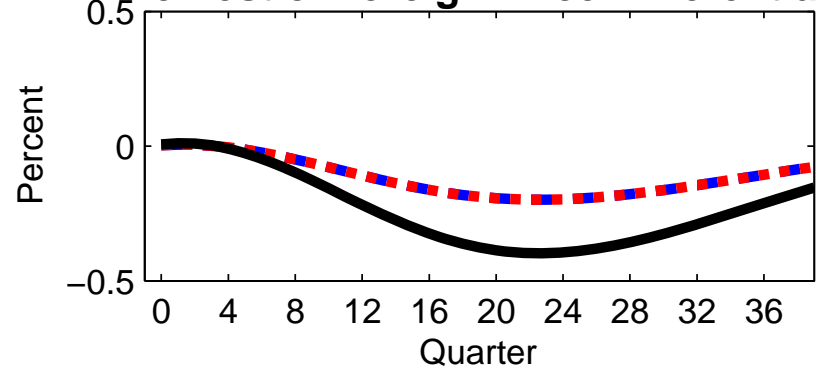

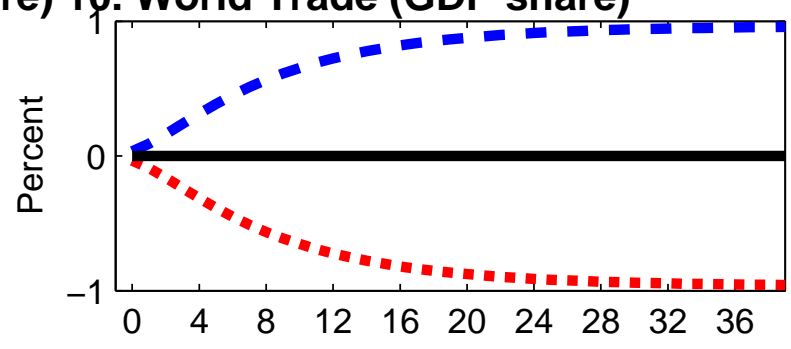

12. Domestic Nominal Exchange Rate

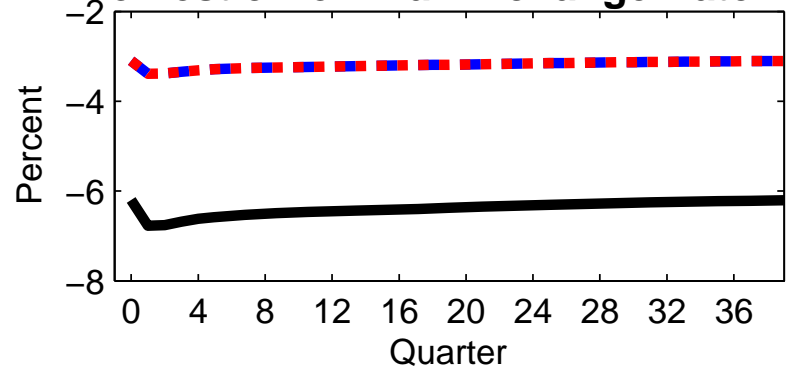


Figure 4: Combined Effects of Imp. Tariffs and Exp. Subsidies Under NER Pegs.
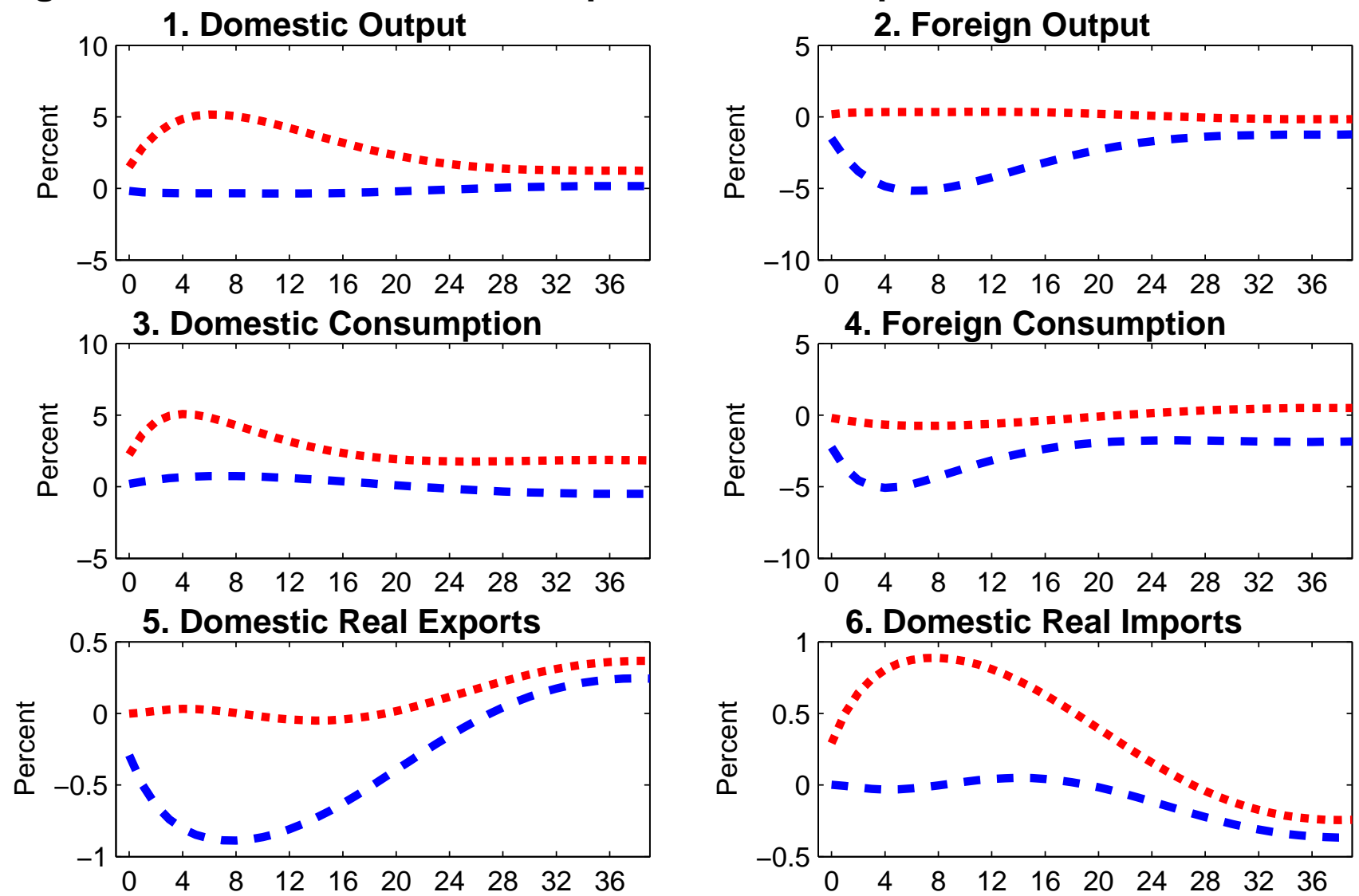

7. Domestic Nominal Trade Balance
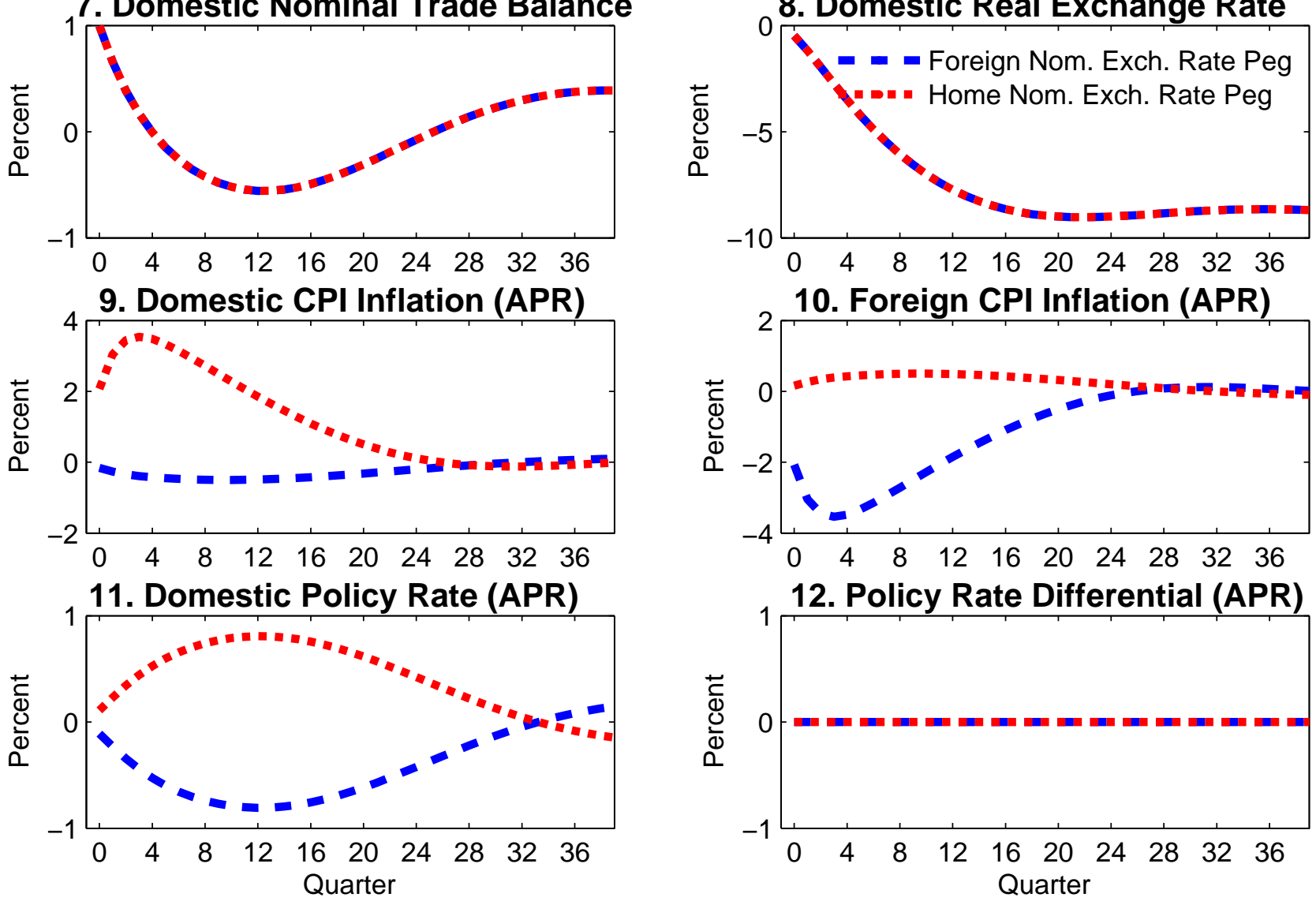
Figure 5: Combined Effects of Tariffs and Subsidies Under Direct Pass-Through.

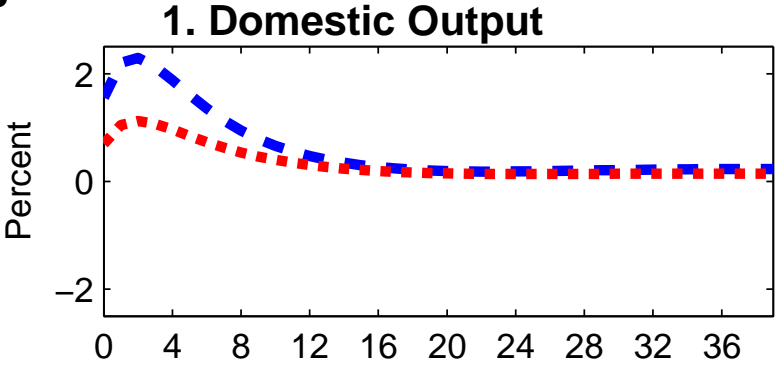

2. Foreign Output

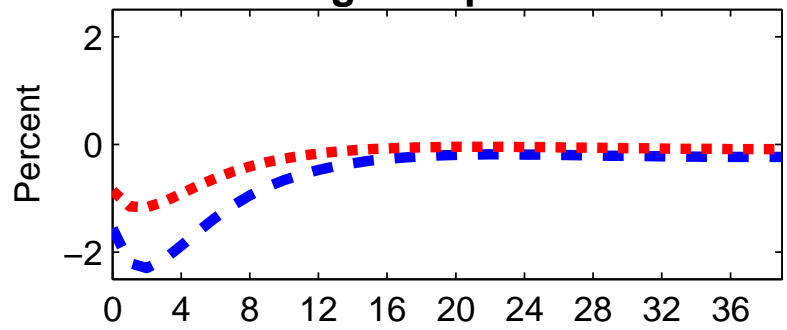

3. Domestic Real Exports
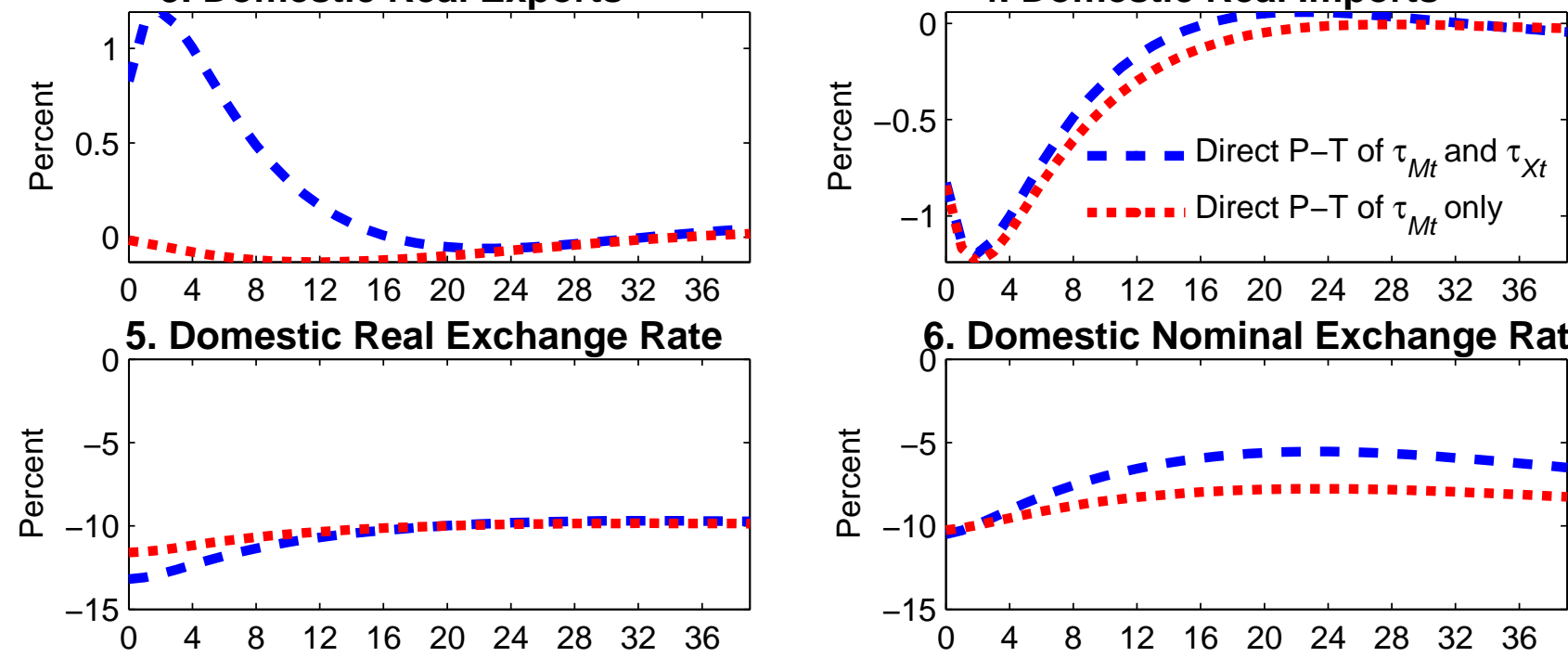

6. Domestic Nominal Exchange Rate

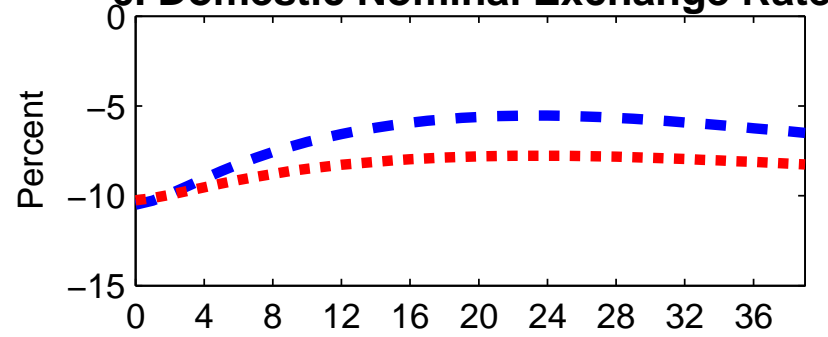

7. World Trade (GDP share)
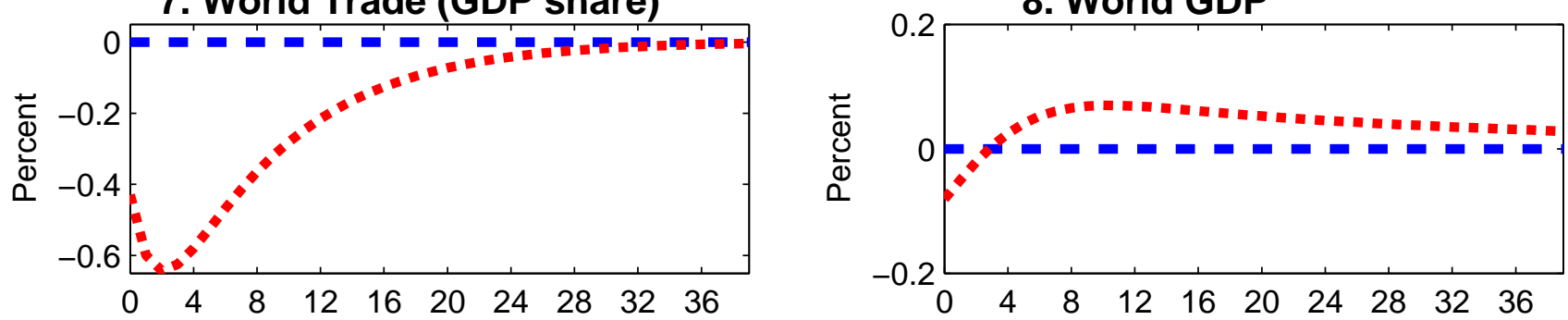

9. Domestic CPI Inflation (APR)

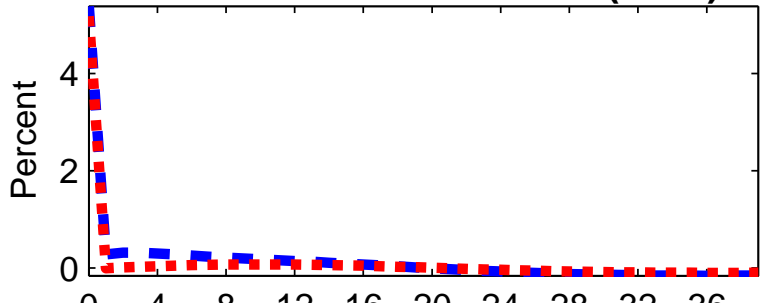

10. Foreign CPI Inflation (APR)

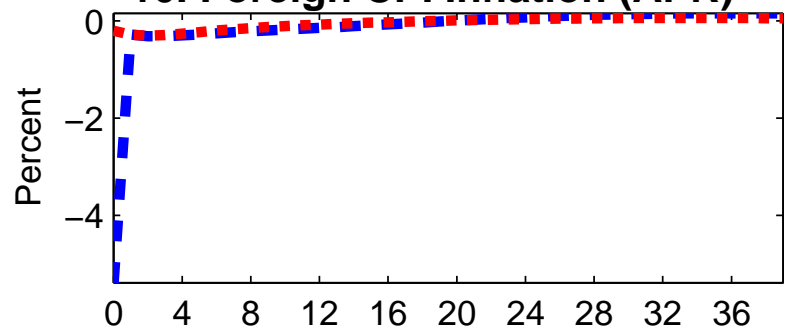

11. Domestic Policy Rate (APR)

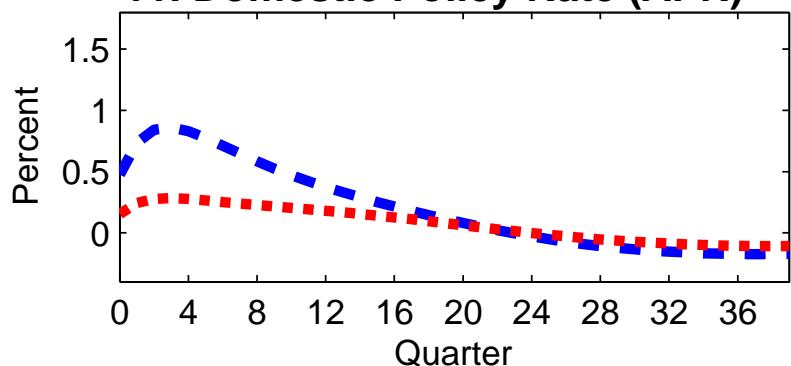

12. Policy Rate Differential (APR)

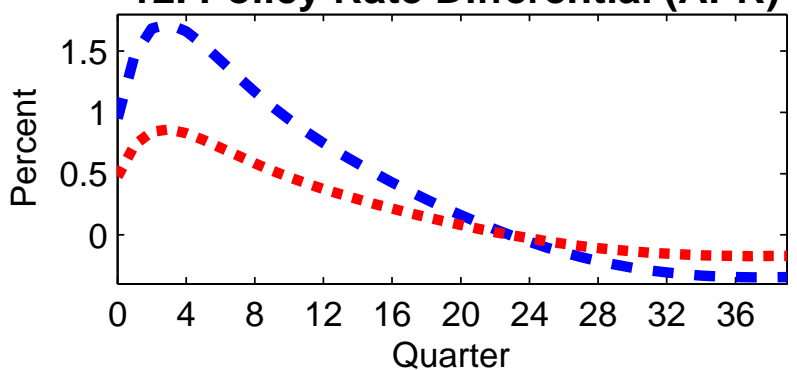




\section{Appendix A. The Open Economy New Keynesian Model}

The large-scale model closely follows Erceg, Guerrieri and Gust (2006) and Erceg and Lindé (2013). The model consists of two equally sized countries (or regions) - home and foreign - and allows for endogenous investment, hand-to-mouth (HM) or "Keynesian" households, sticky wages as well as sticky prices, trade adjustment costs, and incomplete financial markets across the two countries. Given the isomorphic structure of the two countries, our exposition below largely focuses on the structure of the home economy.

As the recent recession has provided strong evidence in favor of the importance of financial frictions, our model also features a financial accelerator channel which closely parallels earlier work by Bernanke, Gertler, and Gilchrist (1999) and Christiano, Motto, and Rostagno (2008). Given that the mechanics underlying this particular financial accelerator mechanism are well-understood, we simplify our exposition by focusing on a special case of our model which abstracts from the financial accelerator. However, we conclude our model description with a brief description of how the model is modified to include the financial accelerator (Section A.6).

\section{A.1. Firms and Price Setting}

\section{A.1.1. Production of Domestic Intermediate Goods}

There is a continuum of differentiated intermediate goods (indexed by $i \in[0,1]$ ) in the home economy, each of which is produced by a single monopolistically competitive firm. In the domestic market, firm $i$ faces a demand function that varies inversely with its output price $P_{D t}(i)$ and directly with aggregate demand at home $Y_{D t}$ :

$$
Y_{D t}(i)=\left[\frac{P_{D t}(i)}{P_{D t}}\right]^{\frac{-\left(1+\theta_{p}\right)}{\theta_{p}}} Y_{D t},
$$

where $\theta_{p}>0$, and $P_{D t}$ is an aggregate price index defined below. Similarly, firm $i$ faces the following export demand function:

$$
X_{t}(i)=\left[\frac{P_{M t}^{*}(i)}{P_{M t}^{*}}\right]^{\frac{-\left(1+\theta_{p}\right)}{\theta_{p}}} M_{t}^{*},
$$

where $X_{t}(i)$ denotes the quantity demanded of domestic good $i$ in the foreign block, $P_{M t}^{*}(i)$ denotes the price that firm $i$ sets in the foreign market, $P_{M t}^{*}$ is the import price index abroad, and $M_{t}^{*}$ is an aggregate of the home's imports (we use an asterisk to denote the foreign's variables).

Each producer utilizes capital services $K_{t}(i)$ and a labor index $L_{t}(i)$ (defined below) to produce its respective output good. The production function is assumed to have a constant-elasticity of 
substitution (CES) form:

$$
Y_{t}(i)=\left(\omega_{K}^{\frac{\rho}{1+\rho}} K_{t}(i)^{\frac{1}{1+\rho}}+\omega_{L}^{\frac{\rho}{1+\rho}}\left(Z_{t} L_{t}(i)\right)^{\frac{1}{1+\rho}}\right)^{1+\rho}
$$

The production function exhibits constant-returns-to-scale in both inputs, and $Z_{t}$ is a countryspecific shock to the level of technology. Firms face perfectly competitive factor markets for hiring capital and labor. Thus, each firm chooses $K_{t}(i)$ and $L_{t}(i)$, taking as given both the rental price of capital $R_{K t}$ and the aggregate wage index $W_{t}$ (defined below). Firms can costlessly adjust either factor of production, which implies that each firm has an identical marginal cost per unit of output, $M C_{t}$. The (log-linearized) technology shock is assumed to follow an $\operatorname{AR}(1)$ process:

$$
z_{t}=\rho_{z} z_{t-1}+\varepsilon_{z, t}
$$

The prices of the intermediate goods are determined by Calvo-style staggered contracts (see Calvo, j1983). In each period, a firm selling its goods in the home market faces a constant probability, $1-\xi_{p}$, of being able to re-optimize its price $\left(P_{D t}(i)\right)$. This probability of receiving a signal to reoptimize is independent across firms and time. If a firm is not allowed to optimize its prices, we follow Christiano, Eichenbaum and Evans (2005) and Smets and Wouters (2003), and assume that the firm must reset its home price as a weighted combination of the lagged and steady state rate of inflation $P_{D t}(i)=\pi_{t-1}^{\iota_{p}} \pi^{1-\iota_{p}} P_{D t-1}(i)$ for the non-optimizing firms. This formulation allows for structural persistence in price-setting if $\iota_{p}$ exceeds zero.

When a firm $i$ is allowed to reoptimize its price in period $t$, the firm maximizes:

$$
\max _{P_{D t}(i)} \mathbb{E}_{t} \sum_{j=0}^{\infty} \psi_{t, t+j} \xi_{p}^{j}\left[\prod_{h=1}^{j} \pi_{t+h-1}\left(P_{D t}(i)-M C_{t+j}\right) Y_{D t+j}(i)\right] .
$$

The operator $\mathbb{E}_{t}$ represents the conditional expectation based on the information available to agents at period $t$. The firm discounts profits received at date $t+j$ by the state-contingent discount factor $\psi_{t, t+j}$; for notational simplicity, we have suppressed all of the state indices. ${ }^{\text {A.1 }}$ The first-order condition for setting the contract price of good $i$ is:

$$
\mathbb{E}_{t} \sum_{j=0}^{\infty} \psi_{t, t+j} \xi_{p}^{j}\left(\frac{\prod_{h=1}^{j} \pi_{t+h-1}(i) P_{D t}(i)}{\left(1+\theta_{p}\right)}-M C_{t+j}\right) Y_{D t+j}(i)=0 .
$$

For the goods sold abroad, we assume local currency pricing (LCP) as explained in Section 2.1. Although the price-setting problem for the exporting firms is isomorphic to the problem for

\footnotetext{
A.1 We define $\xi_{t, t+j}$ to be the price in period $t$ of a claim that pays one dollar if the specified state occurs in period $t+j$ (see the household problem below); then the corresponding element of $\psi_{t, t+j}$ equals $\xi_{t, t+j}$ divided by the probability that the specified state will occur.
} 
the firms selling its goods on the domestic market (and we assume $\xi_{m}=\xi_{p}$ and $\iota_{m}=\iota_{p}$ ), the LCP assumption implies that the price of foreign import goods $P_{M, t}^{*}$ will deviate from the producer currency price $\frac{P_{X, t}}{S_{t}} \times \frac{\left(1+\tau_{M, t}^{*}\right)}{1+\tau_{X, t}}$ as follows (in log-linear form)

$$
\delta_{t}^{*}=-p_{M, t}^{*}-s_{t}+p_{X, t}+\tau_{M, t}^{*}-\tau_{X, t}
$$

where $p_{X, t}=p_{D, t}$. The deviations from the law of one price is due to price stickiness, the foreign import tariffs $\left(\tau_{M, t}^{*}\right)$ and export subsidy the home block provides $\left(\tau_{X, t}\right)$.

\section{A.1.2. Production of the Domestic Output Index}

Because households have identical Dixit-Stiglitz preferences, it is convenient to assume that a representative aggregator combines the differentiated intermediate products into a composite homeproduced good $Y_{D t}$ :

$$
Y_{D t}=\left[\int_{0}^{1} Y_{D t}(i)^{\frac{1}{1+\theta_{p}}} d i\right]^{1+\theta_{p}} .
$$

The aggregator chooses the bundle of goods that minimizes the cost of producing $Y_{D t}$, taking the price $P_{D t}(i)$ of each intermediate good $Y_{D t}(i)$ as given. The aggregator sells units of each sectoral output index at its unit cost $P_{D t}$ :

$$
P_{D t}=\left[\int_{0}^{1} P_{D t}(i)^{\frac{-1}{\theta_{p}}} d i\right]^{-\theta_{p}} .
$$

We also assume a representative aggregator in the foreign block who combines the differentiated home products $X_{t}(i)$ into a single index for foreign imports:

$$
M_{t}^{*}=\left[\int_{0}^{1} X_{t}(i)^{\frac{1}{1+\theta_{p}}} d i\right]^{1+\theta_{p}}
$$

and sells $M_{t}^{*}$ at price $P_{M, t}^{*}$.

$$
P_{M t}^{*}=\left[\int_{0}^{1} P_{M t}^{*}(i)^{\frac{-1}{\theta_{p}}} d i\right]^{-\theta_{p}}
$$

\section{A.1.3. Production of Consumption and Investment Goods}

Final consumption goods are produced by a representative consumption goods distributor. This firm combines purchases of domestically-produced goods with imported goods to produce a final consumption good $\left(C_{A t}\right)$ according to a constant-returns-to-scale CES production function:

$$
C_{A t}=\left(\omega_{C}^{\frac{\rho_{C}}{1+\rho_{C}}} C_{D t}^{\frac{1}{1+\rho_{C}}}+\left(1-\omega_{C}\right)^{\frac{\rho_{C}}{1+\rho_{C}}}\left(\varphi_{C t} M_{C t}\right)^{\frac{1}{1+\rho_{C}}}\right)^{1+\rho_{C}}
$$


where $C_{D t}$ denotes the consumption good distributor's demand for the index of domesticallyproduced goods, $M_{C t}$ denotes the distributor's demand for the index of foreign-produced goods, and $\varphi_{C t}$ reflects costs of adjusting consumption imports. The final consumption good is used by both households and by the government. ${ }^{\text {A.2 }}$ The form of the production function mirrors the preferences of households and the government sector over consumption of domestically-produced goods and imports. Accordingly, the quasi-share parameter $\omega_{C}$ may be interpreted as determining the preferences of both the private and public sector for domestic relative to foreign consumption goods, or equivalently, the degree of home bias in consumption expenditure. Finally, the adjustment cost term $\varphi_{C t}$ is assumed to take the quadratic form:

$$
\varphi_{C t}=\left[1-\frac{\varphi_{M_{C}}}{2}\left(\frac{\frac{M_{C t}}{C_{D t}}}{\frac{M_{C t-1}{ }^{a}}{C_{D t-1}}-1}\right)^{2}\right] .
$$

This specification implies that it is costly to change the proportion of domestic and foreign goods in the aggregate consumption bundle, even though the level of imports may jump costlessly in response to changes in overall consumption demand. We assume that the adjustment costs for each distributor depend on distributor's current import ratio $\frac{M_{C t}}{C_{D t}}$ relative to the economy-wide ratio in the previous period ${\frac{M_{C t-1}}{C_{D t-1}}}^{a}$, so that adjustment costs are external to individual distributors.

Given the presence of adjustment costs, the representative consumption goods distributor chooses (a contingency plan for) $C_{D t}$ and $M_{C t}$ to minimize its discounted expected costs of producing the aggregate consumption good:

$$
\begin{aligned}
& \min _{C_{D t+k}, M_{C t+k}} \mathbb{E}_{t} \sum_{k=0}^{\infty} \psi_{t, t+k}\left(P_{D t+k} C_{D t+k}+P_{M t+k} M_{C t+k}\right) \\
& \left.+P_{C t+k}\left[C_{A, t+k}-\left(\omega_{C}^{\frac{\rho_{C}}{1+\rho_{C}}} C_{D t+k}^{\frac{1}{1+\rho_{C}}}+\left(1-\omega_{C}\right)^{\frac{\rho_{C}}{1+\rho_{C}}}\left(\varphi_{C t+k} M_{C t+k}\right)^{\frac{1}{1+\rho_{C}}}\right)^{1+\rho_{C}}\right]\right\} .
\end{aligned}
$$

The distributor sells the final consumption good to households and the government at a price $P_{C t}$, which may be interpreted as the consumption price index (or equivalently, as the shadow cost of producing an additional unit of the consumption good).

We model the production of final investment goods in an analogous manner, although we allow the weight $\omega_{I}$ in the investment index to differ from that of the weight $\omega_{C}$ in the consumption goods index. A.3

\footnotetext{
A.2 Thus, the larger-scale model constrains the import share of government consumption to equal that of private consumption.

A.3 Government spending is assumed to fall exclusively on consumption, so that all investment is private investment.
} 


\section{A.2. Households and Wage Setting}

We assume a continuum of monopolistically competitive households (indexed on the unit interval), each of which supplies a differentiated labor service to the intermediate goods-producing sector (the only producers demanding labor services in our framework) following Erceg, Henderson and Levin (2000). A representative labor aggregator (or "employment agency") combines households' labor hours in the same proportions as firms would choose. Thus, the aggregator's demand for each household's labor is equal to the sum of firms' demands. The aggregate labor index $L_{t}$ has the Dixit-Stiglitz form:

$$
L_{t}=\left[\int_{0}^{1}\left(\zeta N_{t}(h)\right)^{\frac{1}{1+\theta_{w}}} d h\right]^{1+\theta_{w}},
$$

where $\theta_{w}>0$ and $N_{t}(h)$ is hours worked by a typical member of household $h$. The parameter $\zeta$ is the size of a household of type $h$, and effectively determines the size of the population in the home country. The aggregator minimizes the cost of producing a given amount of the aggregate labor index, taking each household's wage rate $W_{t}(h)$ as given, and then sells units of the labor index to the production sector at their unit cost $W_{t}$ :

$$
W_{t}=\left[\int_{0}^{1} W_{t}(h)^{\frac{-1}{\theta w}} d h\right]^{-\theta_{w}} .
$$

The aggregator's demand for the labor services of a typical member of household $h$ is given by

$$
N_{t}(h)=\left[\frac{W_{t}(h)}{W_{t}}\right]^{-\frac{1+\theta_{w}}{\theta_{w}}} L_{t} / \zeta .
$$

We assume that there are two types of households: households that make intertemporal consumption, labor supply, and capital accumulation decisions in a forward-looking manner by maximizing utility subject to an intertemporal budget constraint (FL households, for "forward-looking"); and the remainder that simply consume their after-tax disposable income (HM households, for "hand-to-mouth" households). The latter type receive no capital rental income or profits, and choose to set their wage to be the average wage of optimizing households. We denote the share of

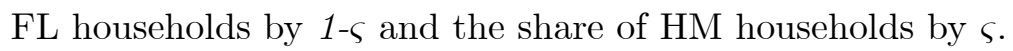

We consider first the problem faced by FL households. The utility functional for an optimizing representative member of household $h$ is

$$
\begin{aligned}
& \mathbb{E}_{t} \sum_{j=0}^{\infty} \beta^{j}\left\{\frac{1}{1-\sigma}\left(C_{t+j}^{O}(h)-\varkappa C_{t+j-1}^{O}-C \nu_{c t+j}\right)^{1-\sigma}+\right. \\
& \left.\frac{\chi_{0} Z_{t+j}^{1-\sigma}}{1-\chi}\left(1-N_{t+j}(h)\right)^{1-\chi}+\mu_{0} F\left(\frac{M B_{t+j+1}(h)}{P_{C t+j}}\right)\right\}
\end{aligned}
$$


where the discount factor $\beta$ satisfies $0<\beta<1$. As in Smets and Wouters (2003, 2007), we allow for the possibility of external habit formation in preferences, so that each household member cares about its consumption relative to lagged aggregate consumption per capita of forward-looking agents $C_{t-1}^{O}$. The period utility function depends on an each member's current leisure $1-N_{t}(h)$, his end-of-period real money balances, $\frac{M B_{t+1}(h)}{P_{C t}}$, and a preference shock, $\nu_{c t}$. The subutility function $F($.) over real balances is assumed to have a satiation point to account for the possibility of a zero nominal interest rate; see Eggertsson and Woodford (2003) for further discussion. A.4 The (log-linearized) consumption demand shock $\nu_{c t}$ is assumed to follow an $\operatorname{AR}(1)$ process:

$$
\nu_{c t}=\rho_{\nu} \nu_{c t-1}+\varepsilon_{\nu_{c}, t}
$$

Forward-looking household $h$ faces a flow budget constraint in period $t$ which states that its combined expenditure on goods and on the net accumulation of financial assets must equal its disposable income:

$$
\begin{gathered}
P_{C t}\left(1+\tau_{C t}\right) C_{t}^{O}(h)+P_{I t} I_{t}(h)+M B_{t+1}(h)-M B_{t}(h)+\int_{s} \xi_{t, t+1} B_{D t+1}(h) \\
-B_{D t}(h)+P_{B t} B_{G t+1}-B_{G t}+S_{t} \frac{P_{B t}^{*} B_{F t+1}(h)}{\phi_{b t}}-S_{t} B_{F t}(h) \\
=\left(1-\tau_{N t}\right) W_{t}(h) N_{t}(h)+\Gamma_{t}(h)+T R_{t}(h)+\left(1-\tau_{K t}\right) R_{K t} K_{t}(h)+ \\
P_{I t} \tau_{K t} \delta K_{t}(h)-P_{D t} \phi_{I t}(h) .
\end{gathered}
$$

Consumption purchases are subject to a sales tax of $\tau_{C t}$. Investment in physical capital augments the per capita capital stock $K_{t+1}(h)$ according to a linear transition law of the form:

$$
K_{t+1}(h)=(1-\delta) K_{t}(h)+I_{t}(h)
$$

where $\delta$ is the depreciation rate of capital.

Financial asset accumulation of a typical member of FL household $h$ consists of increases in nominal money holdings $\left(M B_{t+1}(h)-M B_{t}(h)\right)$ and the net acquisition of bonds. While the domestic financial market is complete through the existence of state-contingent bonds $B_{D t+1}$, crossborder asset trade is restricted to a single non-state contingent bond issued by the government of the foreign economy. ${ }^{\text {A.5 }}$

The terms $B_{G t+1}$ and $B_{F t+1}$ represents each household member's net purchases of the government bonds issued by the home and foreign governments, respectively. Each type of bond pays one currency unit in the subsequent period, and is sold at price (discount) of $P_{B t}$ and $P_{B t}^{*}$, respectively. $S_{t}$ is the nominal exchange rate. To ensure the stationarity of foreign asset positions, we follow

\footnotetext{
${ }^{\text {A.4 }}$ For simplicity, we assume that $\mu_{0}$ is sufficiently small that changes in the monetary base have a negligible impact on equilibrium allocations, at least to the first-order approximation we consider.

A.5 The domestic contingent claims $B_{D t+1}$ are in zero net supply from the standpoint of home economy as a whole.
} 
Turnovsky (1985) by assuming that domestic households must pay a transaction cost when trading in the foreign bond. The intermediation cost depends on the ratio of economy-wide holdings of net foreign assets to nominal GDP, $P_{D t} Y_{D t}$, and are given by:

$$
\phi_{b t}=\exp \left(-\phi_{b}\left(\frac{B_{F t+1}}{P_{D t} Y_{D t}}\right)\right) \text {. }
$$

If the home country is an overall net lender position internationally, then a household will earn a lower return on any holdings of foreign bonds; conversely, if the home country is a net debtor position, home households pay a higher return on their foreign liabilities. Given that the domestic government bond in the home economy and foreign bond have the same payoff, the price faced by home residents net of the transaction cost is identical, so that $P_{B t}=\frac{P_{B t}^{*}}{\phi_{b t}}$. The effective nominal interest rate on domestic bonds (and similarly for foreign bonds) hence equals $i_{t}=1 / P_{B t}-1$.

Each member of FL household $h$ earns after-tax labor income, $\left(1-\tau_{N t}\right) W_{t}(h) N_{t}(h)$, where $\tau_{N t}$ is a stochastic tax on labor income. The household leases capital at the after-tax rental rate $\left(1-\tau_{K t}\right) R_{K t}$, where $\tau_{K t}$ is a stochastic tax on capital income. The household receives a depreciation write-off of $P_{I t} \tau_{K t} \delta$ per unit of capital. Each member also receives an aliquot share $\Gamma_{t}(h)$ of the profits of all firms and a lump-sum government transfer, $T R_{t}(h)$ (which is negative in the case of a tax). Following Christiano, Eichenbaum and Evans (2005), we assume that it is costly to change the level of gross investment from the previous period, so that the acceleration in the capital stock is penalized:

$$
\phi_{I t}(h)=\frac{1}{2} \phi_{I} \frac{\left(I_{t}(h)-I_{t-1}\right)^{2}}{I_{t-1}} .
$$

In every period $t$, each member of FL household $h$ maximizes the utility functional (A.18) with respect to its consumption, investment, (end-of-period) capital stock, money balances, holdings of contingent claims, and holdings of domestic and foreign bonds, subject to its labor demand function (A.17), budget constraint (A.20), and transition equation for capital (A.21). In doing so, a household takes as given prices, taxes and transfers, and aggregate quantities such as lagged aggregate consumption and the aggregate net foreign asset position.

Forward-looking (FL) households set nominal wages in staggered contracts that are analogous to the price contracts described above. In particular, with probability $1-\xi_{w}$, each member of a household is allowed to reoptimize its wage contract. If a household is not allowed to optimize its wage rate, we assume each household member resets its wage according to:

$$
W_{t}(h)=\omega_{t-1}^{\iota_{w}} \omega^{1-\iota_{w}} W_{t-1}(h),
$$


where $\omega_{t-1}$ is the gross nominal wage inflation rate in period $t-1$, i.e. $W_{t} / W_{t-1}$, and $\omega=\pi$ is the steady state rate of change in the nominal wage (equal to gross price inflation since steady state gross productivity growth is assumed to be unity). Dynamic indexation of this form introduces some element of structural persistence into the wage-setting process. Each member of household $h$ chooses the value of $W_{t}(h)$ to maximize its utility functional (A.18) subject to these constraints.

Finally, we consider the determination of consumption and labor supply of the hand-to-mouth (HM) households. A typical member of a HM household simply equates his nominal consumption spending, $P_{C t}\left(1+\tau_{C t}\right) C_{t}^{H M}(h)$, to his current after-tax disposable income, which consists of labor income plus lump-sum transfers from the government:

$$
P_{C t}\left(1+\tau_{C t}\right) C_{t}^{H M}(h)=\left(1-\tau_{N t}\right) W_{t}(h) N_{t}(h)+T R_{t}(h) .
$$

The HM households are assumed to set their wage equal to the average wage of the forwardlooking households. Since HM households face the same labor demand schedule as the forwardlooking households, this assumption implies that each HM household works the same number of hours as the average for forward-looking households.

\section{A.3. Monetary Policy}

The central bank is assumed to adhere to a Taylor-type policy rule although we allow here for some inertia in the interest rate reaction function that is captured by the term $\gamma_{i} i_{t-1}$ :

$$
i_{t}=\left(1-\gamma_{i}\right)\left(\psi_{\pi} \pi_{C t}+\psi_{x} \Delta x_{t}+\psi_{\Delta x} \Delta x_{t}+\gamma_{i} i_{t-1}\right)
$$

where $\pi_{C t}$ is consumer price inflation, and $x_{t}$ is the model consistent output gap, i.e. the percent deviation of actual output from the notional level of output that would prevail if prices and wages were fully flexible.

When monetary policy is subject to the zerlo-lower-bound (ZLB), the policy rule is modified as follows:

$$
i_{t}=\max \left[-i,\left(1-\gamma_{i}\right)\left(\psi_{\pi} \pi_{C t}+\psi_{x} x_{t}+\psi_{\Delta x} \Delta x_{t}+\gamma_{i} i_{t-1}\right)\right]
$$

where $i$ is the steady state nominal interest rate: as before, $i_{t}$ measures the policy rate as a deviation from steady state, so that $i_{t}=-i$ implies that the policy rate is zero when expressed in levels. 


\section{A.4. Fiscal Policy}

The government does not need to balance its budget each period, and issues nominal debt $B_{G t+1}$ at the end of period $t$ to finance its deficits according to:

$$
\begin{aligned}
P_{B, t} B_{G, t+1} & -B_{G, t}=P_{C, t} G_{t}+T R_{t}^{O}+T R_{t}^{H M}-\tau_{N, t} W_{t} L_{t}-\tau_{C, t} P_{C, t} C_{t}-\tau_{K, t}\left(R_{K, t}-\delta P_{I, t}\right) K_{t} \\
& -\left(M B_{t+1}-M B_{t}\right)-\tau_{M, t} P_{M, t} M_{t} /\left(1+\tau_{M, t}\right)+\tau_{X, t} P_{X, t} X_{t} /\left(1+\tau_{X, t}\right),
\end{aligned}
$$

where $C_{t}$ is total private consumption. Equation (A.28) aggregates the capital stock, money and bond holdings, and transfers and taxes over all households so that, for example, $T R_{t}^{O}=$ $\int_{0}^{O} T R_{t}^{O}(h) d h$. The taxes on capital $\tau_{K t}$, consumption $\tau_{C t}$ and labor income $\tau_{N t}$, as well as the ratio of real transfers to (trend) GDP to hand to mouth households, $\operatorname{tr}_{t}^{H M}=\frac{T R_{t}^{H M}}{P_{t} Y}$, are also assumed to be fixed. ${ }^{\text {A.6 }}$ Government purchases have no direct effect on the utility of households, nor do they affect the production function of the private sector.

The process for the (log of) government spending is given by an $\mathrm{AR}(1)$ process:

$$
\left(g_{t}-g\right)=\rho_{G}\left(g_{t-1}-g\right)+\varepsilon_{g, t}
$$

where $\varepsilon_{g, t}$ is independently normally distributed with zero mean and standard deviation $\sigma_{G}$.

We assume that policymakers adjust the ratio of real transfers to (trend) GDP for optimizing households, $t r_{t}^{O}=\frac{T R_{t}^{O}}{P_{t} Y}$, to stabilize the debt/GDP ratio and the deficit. Specifically, the labor tax rate evolves according to:

$$
t r_{t}^{O}-t r^{O}=\nu_{1}\left(t r_{t-1}^{O}-t r^{O}\right)-\left(1-\nu_{1}\right)\left[\nu_{2}\left(b_{G t}-b_{G}\right)+\nu_{3}\left(\Delta b_{G t+1}-\Delta b_{G}\right)\right]
$$

where $b_{G t}=B_{G t} /\left(4 \bar{P}_{t} Y\right)$ (i.e. government debt as share of nominal trend output).

\section{A.5. Resource Constraint and Net Foreign Assets}

The home economy's aggregate resource constraint can be written as:

$$
Y_{D t}=C_{D t}+I_{D t}+\phi_{I t}+\frac{\zeta^{*}}{\zeta} M_{t}^{*}
$$

where $\phi_{I t}$ is the adjustment cost on investment aggregated across all households. The final consumption good is allocated between households and the government:

$$
C_{A t}=C_{t}+G_{t},
$$

A.6 Given that the central bank uses the nominal interest rate as its policy instrument, the level of seigniorage is determined by nominal money demand. 
where $C_{t}$ is (per capita) private consumption of FL (optimizing) and HM households:

$$
C_{t}=(1-\varsigma) C_{t}^{O}+\varsigma C_{t}^{H M}
$$

Total exports may be allocated to either the consumption or the investment sector abroad:

$$
M_{t}^{*}=M_{C t}^{*}+M_{I t}^{*}
$$

The evolution of net foreign assets can be expressed as:

$$
\frac{P_{B, t}^{*} B_{F, t+1}}{\phi_{b t}}=B_{F, t}+P_{M t}^{*} \frac{\zeta^{*}}{\zeta} M_{t}^{*}-P_{M t} M_{t}
$$

This expression can be derived from the budget constraint of the FL households after imposing the government budget constraint, the consumption rule of the HM households, the definition of firm profits, and the condition that domestic state-contingent non-government bonds $\left(B_{D t+1}\right)$ are in zero net supply

Finally, we assume that the structure of the foreign country is isomorphic to that of the home country.

\section{A.6. Production of capital services}

The model is amended to include a financial accelerator mechanism into both country blocks of our benchmark model following the basic approach of Bernanke, Gertler and Gilchrist (1999). Thus, the intermediate goods producers rent capital services from entrepreneurs (at the price $R_{K t}$ ) rather than directly from households. Entrepreneurs purchase physical capital from competitive capital goods producers (and resell it back at the end of each period), with the latter employing the same technology to transform investment goods into finished capital goods as described by equations A.21) and A.23). To finance the acquisition of physical capital, each entrepreneur combines his net worth with a loan from a bank, for which the entrepreneur must pay an external finance premium (over the risk-free interest rate set by the central bank) due to an agency problem. Banks obtain funds to lend to the entrepreneurs by issuing deposits to households at the interest rate set by the central bank, with households bearing no credit risk (reflecting assumptions about free competition in banking and the ability of banks to diversify their portfolios). In equilibrium, shocks that affect entrepreneurial net worth - i.e., the leverage of the corporate sector - induce fluctuations in the corporate finance premium. ${ }^{\text {A.7 }}$

\footnotetext{
A.7 We follow Christiano, Motto and Rostagno (2008) by assuming that the debt contract between entrepreneurs and banks is written in nominal terms (rather than real terms as in Bernanke, Gertler and Gilchrist, 1999). For further details about the setup, see Bernanke, Gertler and Gilchrist (1999), and Christiano, Motto and Rostagno (2008). An excellent exposition is also provided in Christiano, Trabandt and Walentin (2007).
} 


\section{A.7. Solution Method and Calibration}

To analyze the behavior of the model, we log-linearize the model's equations around the nonstochastic steady state. Nominal variables are rendered stationary by suitable transformations. To solve the unconstrained version of the model, we compute the reduced-form solution of the model for a given set of parameters using the numerical algorithm of Anderson and Moore (1985), which provides an efficient implementation of the solution method proposed by Blanchard and Kahn (1980). When we solve the model subject to the non-linear monetary policy rule (A.27), we use the techniques described in Hebden, Lindé and Svensson (2009). An important feature of the Hebden, Lindé and Svensson algorithm is that the duration of the liquidity trap is endogenously determined. ${ }^{\text {A.8 }}$

The model is calibrated at a quarterly frequency. The country size parameter $\zeta=1$, so that the home and foreign countries are equally large. The trade share of the home economy is set to 18 percent of its GDP, which intended to match U.S. trade with the rest of the world. This pins down the trade share parameters $\omega_{C}$ and $\omega_{I}$ for the home country under the additional assumption that the import intensity of consumption is equal to $3 / 4$ that of investment. The trade share of the foreign economy is thus 7.5 percent. We assume that $\rho_{C}=\rho_{I}=2.5$, which together with our price markup $\theta_{p}=0.2$ is consistent with a long-run price elasticity of demand for imported consumption and investment goods of 1.5. The import adjustment cost parameters are set so that $\varphi_{M_{C}}=\varphi_{M_{I}}=1$, which slightly damps the near-term relative price sensitivity. The financial intermediation parameter $\phi_{b}$ is set to a very small value (0.00001), which is sufficient to ensure the model has a unique steady state.

The utility functional parameter $\sigma$ is set equal to 1 to ensure that the model exhibit balanced growth, while the $\varkappa$ parameter determining the degree of habit persistence in consumption is set to 0.8 (following empirical evidence). The Frisch elasticity of labor supply is set to 0.4 (so $\chi=2.5)$. The utility parameter $\chi_{0}$ is set so that employment comprises one-third of the household's time endowment, while the parameter $\mu_{0}$ on the subutility function for real balances is set at an arbitrarily low value (so that variation in real balances do not affect equilibrium allocations). We set the share of HM agents $\varsigma=0.5$, implying that these agents account for about one quarter of aggregate private consumption spending (the latter is much smaller than the population share of HM agents because the latter own no capital).

The parameter determining investment adjustment costs is estimated to be $\phi_{I}=3$. The

\footnotetext{
A.8 In future work, it would be of interest to solve the model in a fully non-linear form.
} 
depreciation rate of capital $\delta$ is set at 0.03 (consistent with an annual depreciation rate of 12 percent). The parameter $\rho$ in the CES production function of the intermediate goods producers is set to -2 , implying an elasticity of substitution between capital and labor $(1+\rho) / \rho$, of $1 / 2$. The quasi-capital share parameter $\omega_{K}$ - together with the price markup parameter of $\theta_{P}=0.20$ - is chosen to imply a steady state investment to output ratio of 20 percent. In the augmented version of the model with a financial accelerator, our calibration of parameters follows Bernanke, Gertler and Gilchrist (1999). In particular, the monitoring cost, $\mu$, expressed as a proportion of entrepreneurs' total gross revenue, is set to 0.12. The default rate of entrepreneurs is 3 percent per year, and the variance of the idiosyncratic productivity shocks to entrepreneurs is 0.28 .

The Calvo price contract duration parameters are set to be $\xi_{p}=\xi_{m}=0.92$, while the wage contract duration parameter is estimated to be $\xi_{w}=0.90$. We set the degree of price indexation $\iota_{p}=0.5$ and wage indexation $\iota_{w}$ to unity, while the wage markup $\theta_{W}=1 / 3{ }^{\text {A.9 }}$ The parameters of the monetary rule are set such that $\gamma_{\pi}=2.5, \gamma_{x}=0.125, \gamma_{\Delta x}=\gamma_{x} / 2$, and $\gamma_{i}=0.7$. With the discount factor set at $\beta=0.995$ and the inflation target at 2 percent, the steady state nominal interest rate is 4 percent.

The parameters pertaining to fiscal policy are intended to roughly capture the revenue and spending sides of the U.S. government budgets. The share of government spending on goods and services is set equal to 18 percent of steady state output. The government debt to GDP ratio, $b_{G}$, is set to 0.90 , roughly equal to the average level of consolidated federal debt at end-2016. The ratio of transfers to GDP is set to 7.5 percent. The steady state sales (i.e., VAT) tax rate $\tau_{C}$ is set to 6 percent, while the capital tax $\tau_{K}$ is set to 0.30 . Given the annualized steady state real interest rate (of 2 percent), the government's intertemporal budget constraint then implies that the labor income tax rate $\tau_{N}$ equals 0.375 in steady state. We assume an unaggressive tax adjustment rule in (A.30) by setting $\nu_{1}=0.985$ and $\nu_{2}=\nu_{3}=.1$.

\section{Appendix B. $\quad$ Additional Results}

In this appendix, we present some additional results referred to in the main text.

\footnotetext{
${ }^{\text {A.9 }}$ Given strategic complementarities in wage-setting, the wage markup influences the slope of the wage Phillips
} Curve. 


\section{B.1. Effects on Flexible Price-Wage Allocations}

In Figure B.1 we report the results on the allocations in the notional equilibrium with flexible prices and wages of exactly the same experiment as in Figure 1. As some variables in Figure 1 are specific to the sticky price version of the economy, those variables are replaced with other ones in the figures (potential real rate and investment at home and abroad).

\section{B.2. Results Under Producer Currency Pricing}

In Figure B.2 we report the effects of exactly the same experiment as in Figure 1 but under PCP instead of LCP assumption.

\section{B.3. Results Under Home Currency Invoicing}

In Figure B.3 we report the effects of exactly the same experiment as in Figure 1, but under the alternative assumption that all trades goods are priced in the home currency when they are traded. Technically, we implement this by assumption LCP in the home import sector, but PCP for the home export (foreign import) sector. 
Figure B.1: Effects of Import Tariffs and Export Subsidies on Flex-price Equilibrium.

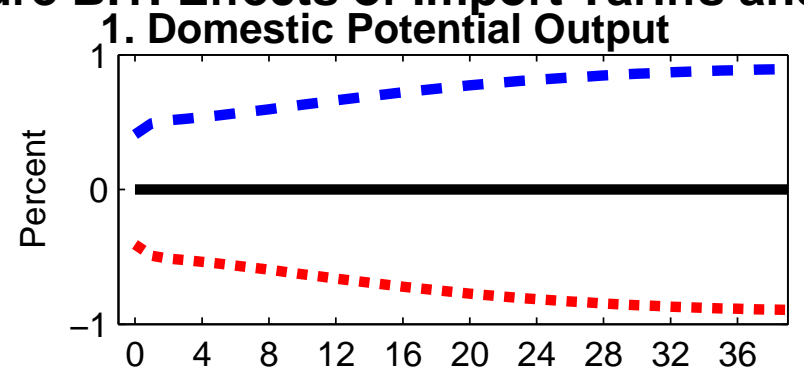

3. Home Pot. Cons. of Imported Goods

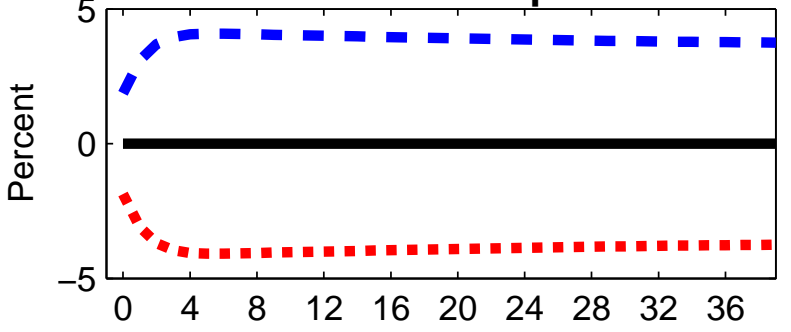

5. Domestic Potential Real Exports

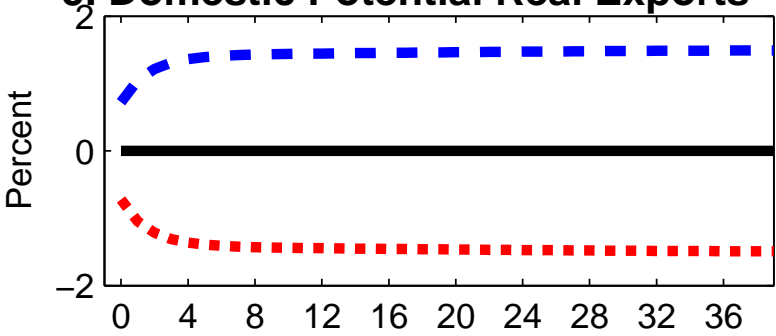

7, Domestic Potential Trade Balance

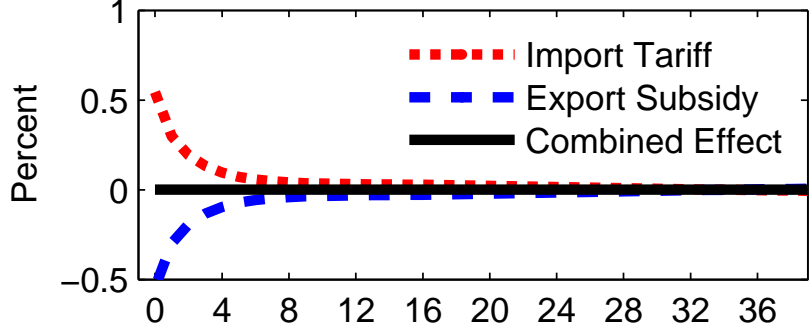

9. Domestic Potential Real Exchange Rate

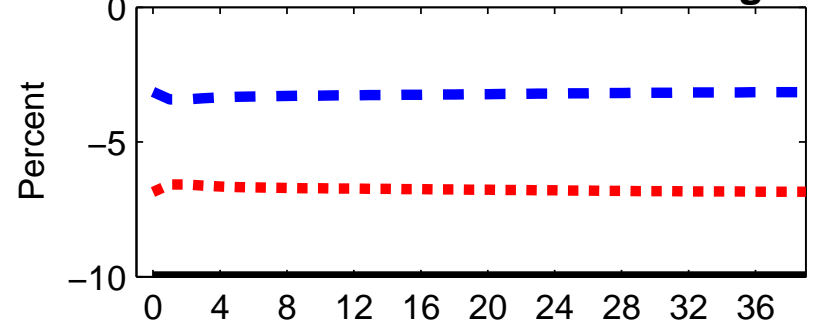

11. Domestic Potential Invest

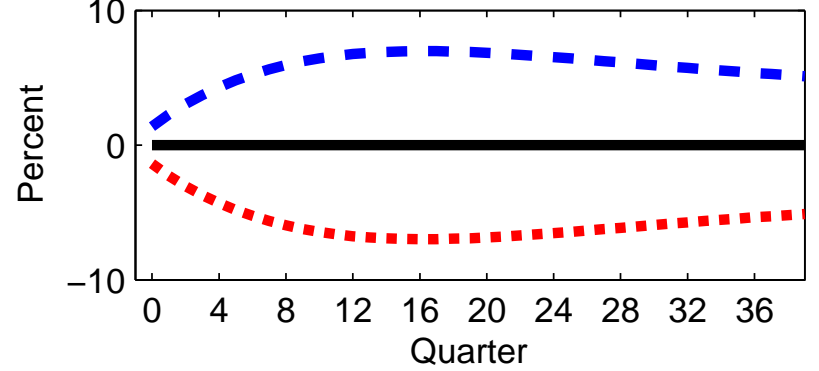

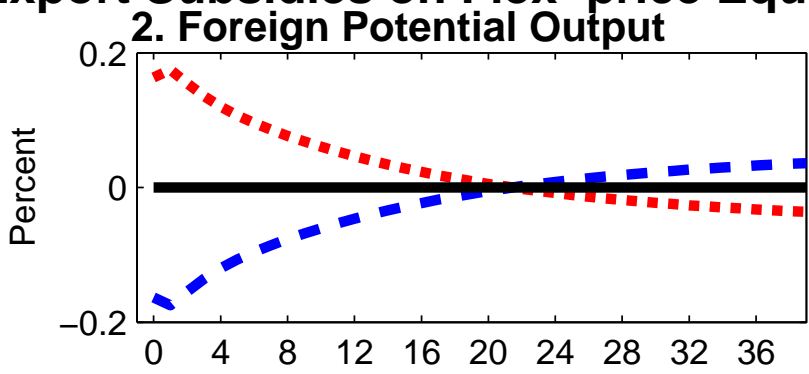

4, Foreign Pot. Cons. of Imported Goods
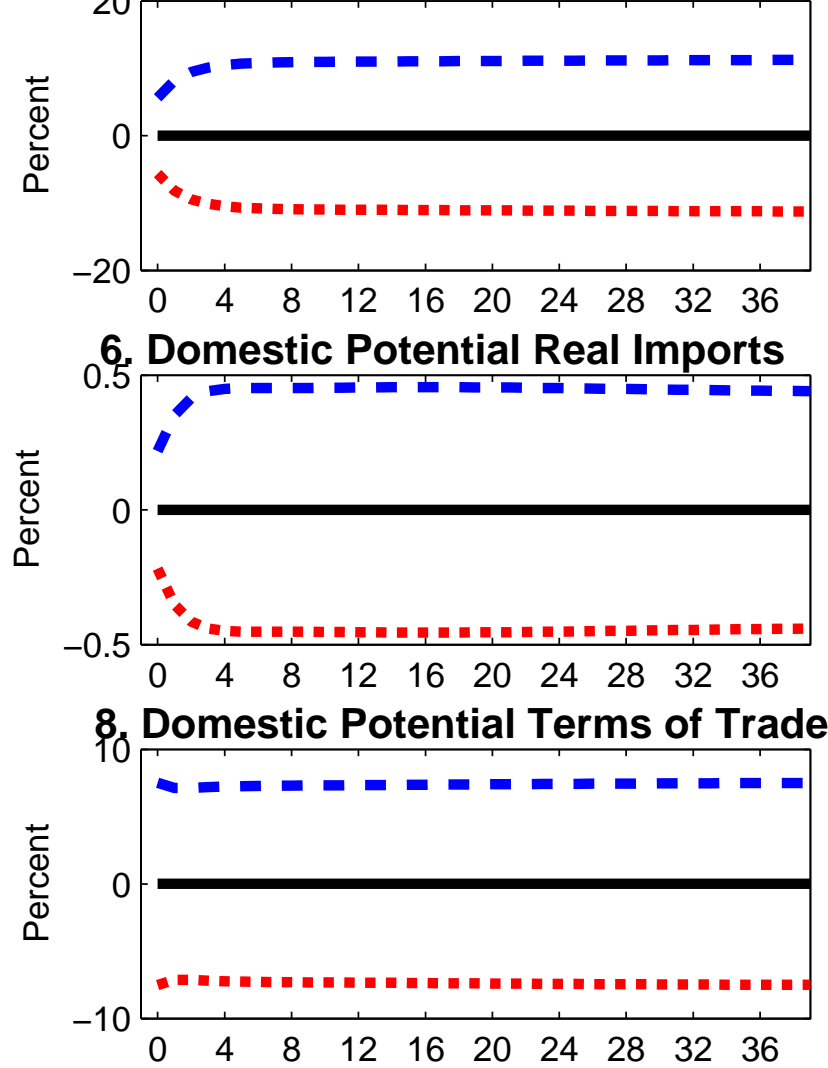

$$
\begin{aligned}
& 0 \\
& 0 \\
& 0 \\
& 0 \\
& 0 \\
& 0 \\
& 0
\end{aligned}
$$

10. Domestic Real Int Rate (APR)

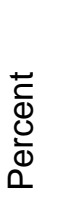
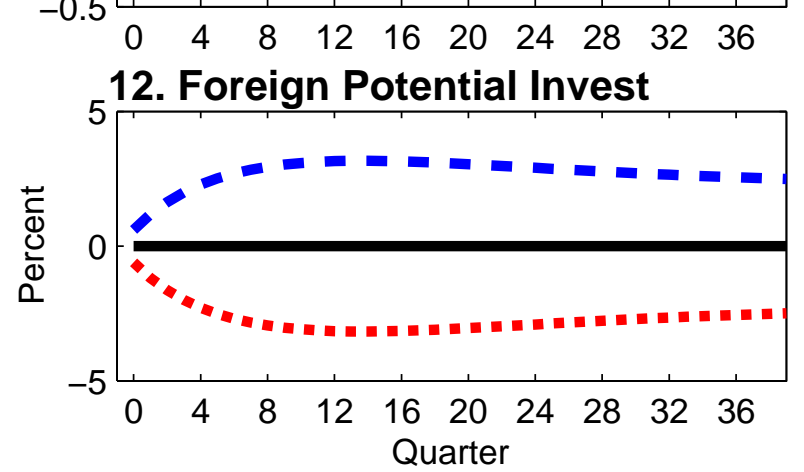
Figure B.2: Effects of Permanent Import Tariffs and Export Subsidies Under PCP.

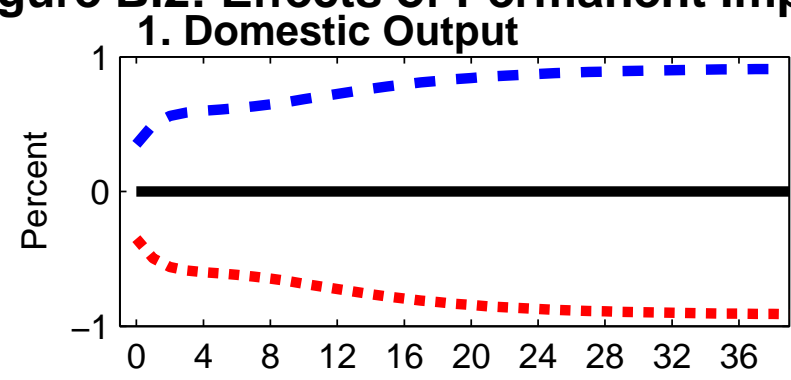

3. Home Consumption of Imported Goods

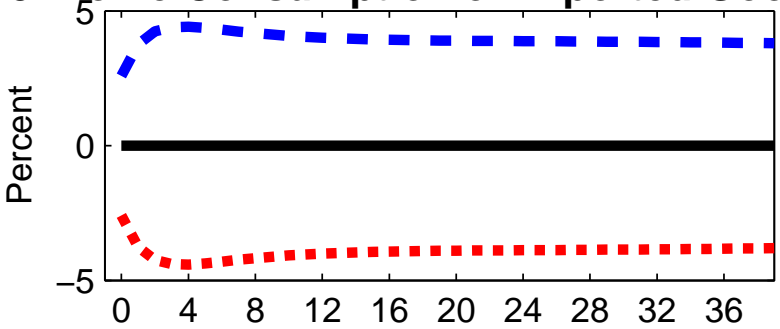

5. Domestic Real Exports

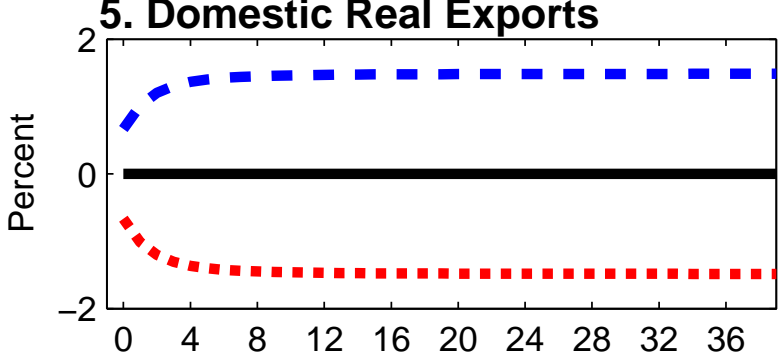

7. Domestic Nominal Trade Balance

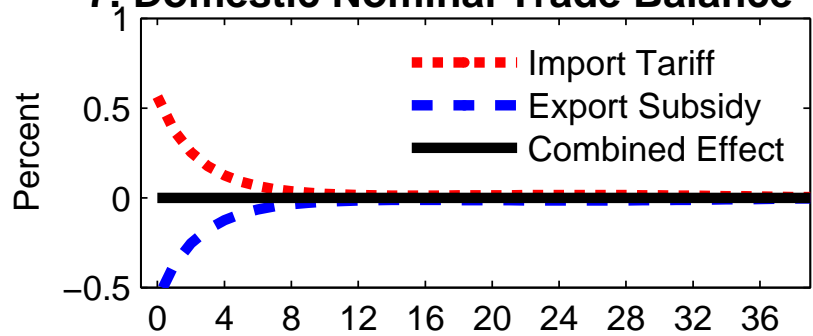

9 , Domestic Real Exchange Rate

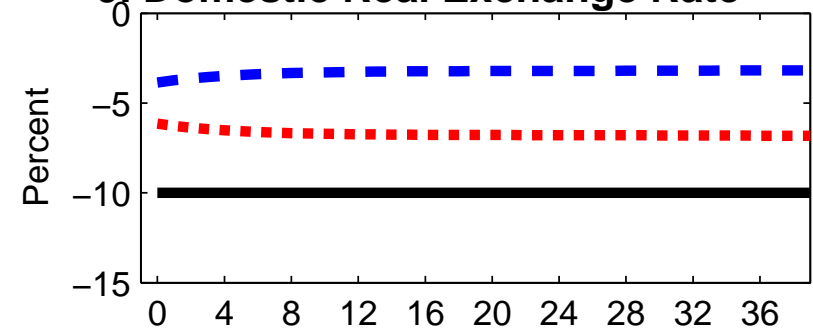

11. Domestic Policy Rate (APR)

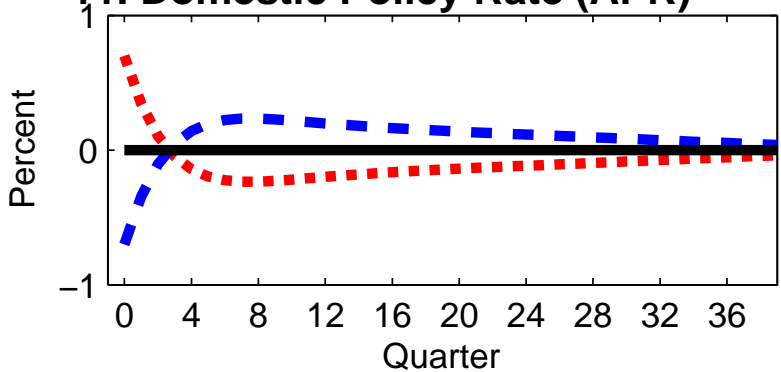

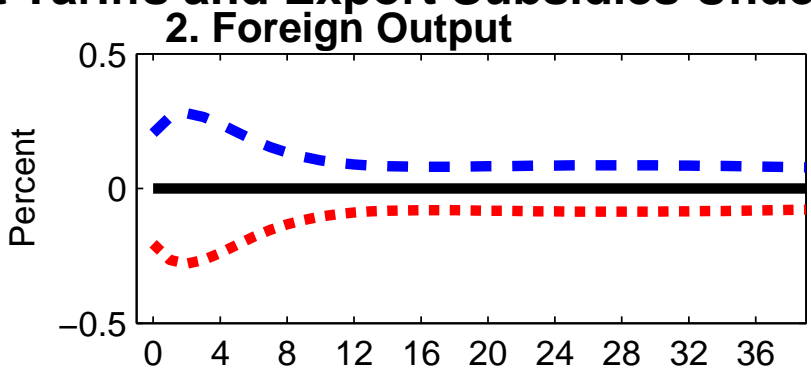

4. Foreign Consumption of Imported Goods
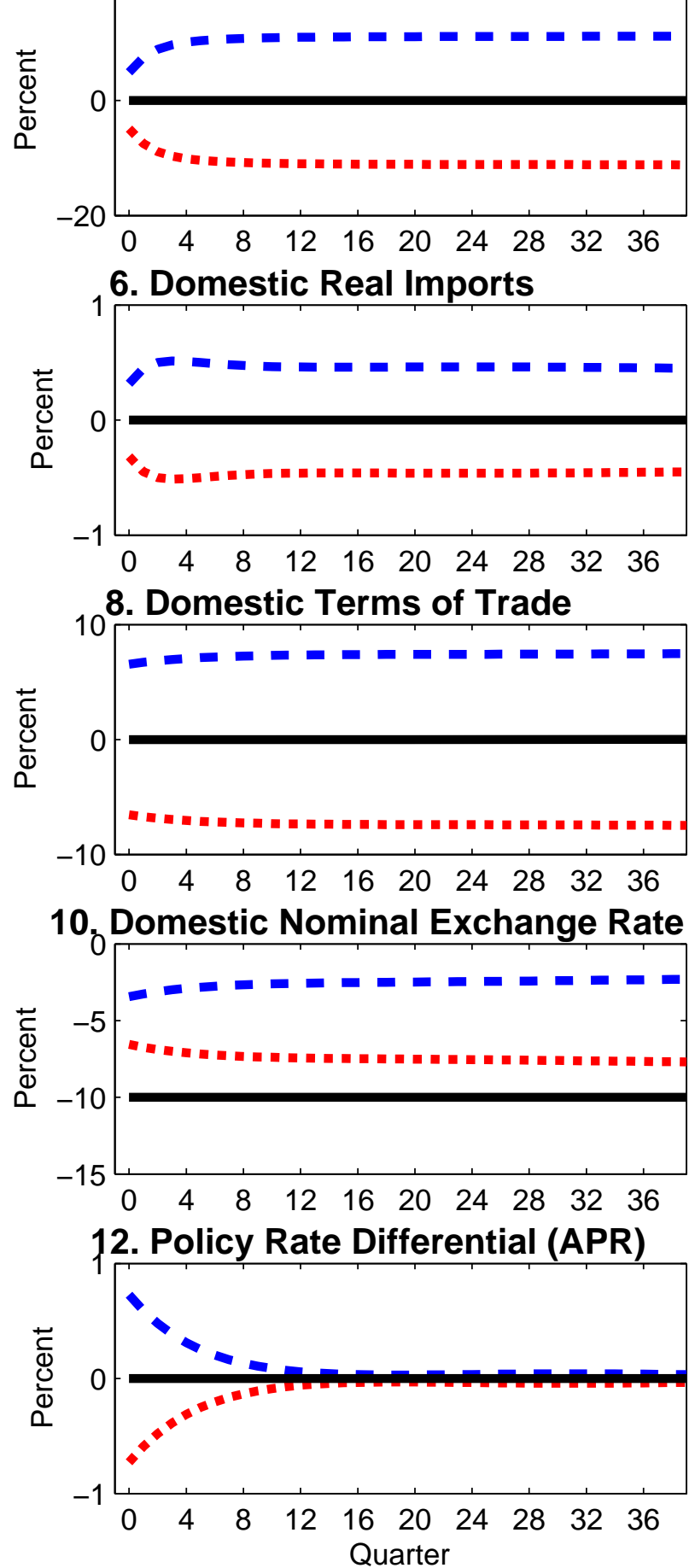


\section{Appendix C. $\quad$ Analytical Results under Complete Markets}

In this appendix, we show that uncertainty about trade policy rather than the introduction of tariffs and subsidies per se is the key mechanism whereby the complete markets assumption causes deviations from Lerner symmetry. We first outline the model setup. Next, we show that Lerner symmetry holds when there is no trade policy uncertainty. Finally, we establish the breakdown from the equivalence when there is uncertainty.

\section{C.1. Model Setup}

Following Dellas and Stockman (1986), we assume an endowment world economy where there are two countries, two tradable goods $(X$ and $Y$ ) that are endowments for both countries, and 4 state of the world. In State 0 there are no tariffs, in State 1 the home country imposes an import tariff $\tau$. In State 2, the home country imposes and export subsidy $\sigma$ and in State 3 the home economy imposes both an import tariff and an export subsidy. Each state has a probability $\pi_{i} \geq 0, i=1, \ldots, 3$. We will denote the foreign country variables with an asterisk $\left(^{\star}\right)$.

The endowment of the two goods for the home country is $\bar{X}$ and $\bar{Y}$, and $\bar{X}^{\star}$ and $\bar{Y}^{\star}$ in the foreign country. Moreover, it is assumed that $\bar{X} / \bar{Y}$ and $\bar{Y}^{\star} / \bar{X}^{\star}$ are sufficiently high so that the home (foreign) country is an exporter of good $X(Y)$ in equilibrium.

Households in both countries have a separable and symmetric utility function $U(x, y)=\ln x+$ $\ln y$. The government collects the revenues from the import tariff and extend export subsidies to export firms. It balances its budget each period through lump sum taxes, $T$, which are extended to the households.

\section{C.2. Deterministic Trade Policy}

In the absence of trade policy uncertainty, we consider the state when the government introduces an import tariff $\tau$ and export subsidy $\sigma$ with certainty. Formally, this means that we set $\pi_{3}=1$ and $\pi_{1}=\pi_{2}=\pi_{4}=0$. In this case, the household problem in the home economy is

$$
\begin{aligned}
& \max _{x, y} U(x, y) \\
& -T=p(\bar{X}-x)(1+\sigma)+q(\bar{Y}-y)(1+\tau)
\end{aligned}
$$

where $p$ and $q$ are the price of $x$ and $y$, respectively. A similar problem holds for the foreign country with $\sigma^{\star}=\tau^{\star}=0$. 
The first order conditions are (where $\lambda$ is the lagrange multiplier associated to the budget constraint)

$$
\begin{aligned}
& 1 / x=\lambda p(1+\sigma) \\
& 1 / y=\lambda q(1+\tau)
\end{aligned}
$$

A similar pair of equations hold for the foreign country. No arbitrage conditions also imply that $p=p^{\star}(1+\sigma)$ and $q=q^{\star}(1+\tau)$. We set $p^{\star}=1$ as numeraire.

If the export subsidy equals the import tariff, $\sigma=\tau$, eqs. (C.37) and (C.38) can be combined to show that relative prices are undistorted by the trade policy within a country $q / p=q^{\star} / p^{\star}=$ $X^{w} / Y^{w}$, where $X^{w}=\bar{X}+\bar{X}^{\star}$ is global production of good $X$ (similarly for $Y$ ). The terms of trade $p / q$ and the real allocation are, thus, not affected by the trade policy. ${ }^{\text {C.10 }}$

The real exchange rate $E$, however, will move with the policy. Following the workhorse model, the real exchange rate is defined as $E=P^{\star} / P$ where $P=\omega p+(1-\omega) q$ and $P^{\star}=\omega p^{\star}+(1-\omega) q^{\star}$, for some allocation share of the $X$ and $Y$ goods $\omega \geq 0$. Hence, we have $\mathcal{E}=P^{\star} / P=1 /(1+\tau)$

Since prices are free to adjust, the introduction of an import tariff and export subsidy appreciates the home-country real exchange rate while keeping relative prices unaffected. While consumption volumes are unaffected, the relative value of the home consumption bundle, $C / C^{*} \equiv$ $(p x+q y) /\left(p^{*} x^{*}+q^{*} y^{*}\right)=1+\tau$, increases at rate $\tau$. In fact, the additional value of money (i.e., the shadow price of government transfers) is lower in the home country $\lambda<\lambda^{\star}$.

\section{C.3. Trade Policy Uncertainty}

Now we consider the general case with uncertainty about trade policy, i.e. $\pi_{i}>0 \forall i$. The representative consumer of both countries can trade Arrow-Debreu securities (i.e., claims of a unit of $\operatorname{good} i$ in state $j$ ) to maximize

$$
\begin{aligned}
\max _{x, y} & \sum_{i=0}^{3} \pi_{i} U\left(x_{i}, y_{i}\right) \\
& \text { s.t. } \\
-T_{i} & =p_{i}\left(\bar{X}-x_{i}\right)\left(1+\sigma_{i}\right)+q_{i}\left(\bar{Y}-y_{i}\right)\left(1+\tau_{i}\right)
\end{aligned}
$$

Where $p_{i}$ and $q_{i}$ are the prices of the claims. ${ }^{\text {C.11 }}$ The foreign consumer faces a similar problem but in this country tariffs and subsidies are zero in all states, that is $\sigma_{i}^{\star}=\tau_{i}^{\star}=0 \forall i$.

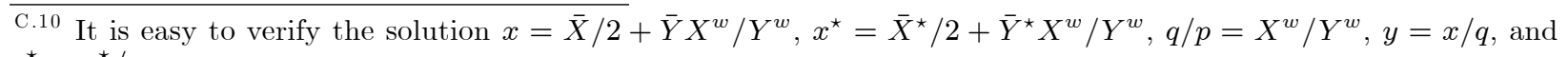
$y^{\star}=x^{\star} / q$.

C.11 Recall that we have assumed $\sigma_{0}=\tau_{0}=0, \sigma_{1}=0$ and $\tau_{1}=\tau, \sigma_{2}=\sigma$ and $\tau_{2}=0$, and $\sigma_{3}=\sigma$ and $\tau_{3}=\tau$.
} 
Without loss of generality, we assume that the two countries are symmetric $\bar{X}=\bar{Y}^{\star}$ and $\bar{Y}=\bar{X}^{\star}$. In this case, in State 0 consumption must be symmetric $x_{0}=y_{0}=x_{0}^{\star}=y_{0}^{\star}=X^{w} / 2$ and prices undistorted $p_{0}=q_{0}$. This allows us to determine the lagrange multiplier associated with an additional unit of money as

$$
\lambda=\lambda^{\star}=0.5 \pi_{0} /\left(p_{0} X^{w}\right)=0.5 \pi_{0} / X^{w}
$$

having set $p_{0}=1$ as numeraire. ${ }^{\text {C.12 }}$ The fact that the shadow value of an additional unit of money is constant across countries is a departure from the deterministic case previously studied and will be key to understand the departure from the Lerner equivalence.

State of the world with import tariff and export subsidy In this case the price distortion induced by the tariffs is symmetric for net exported and imported good such that $p_{3} / q_{3}=1$. However, since in equilibrium contracts ensure that the marginal utility from an additional unit of money is proportional between home and foreign consumers in all states, the following relationships has to hold in State 3:

$$
\begin{aligned}
& \lambda p_{3} / \pi_{3}=\frac{1}{(1+\sigma) x_{3}}=\frac{1}{x_{3}^{\star}}, \\
& \lambda q_{3} / \pi_{3}=\frac{1}{(1+\tau) y_{3}}=\frac{1}{y_{3}^{\star}} .
\end{aligned}
$$

As a result, the value of the consumption is equated across the two countries

$$
C_{3}=(1+\tau) p_{3} x_{3}+(1+\sigma) q_{3} y_{3}=p_{3} x_{3}^{\star}+q_{3} y_{3}^{\star}=C_{3}^{\star},
$$

but the Lerner symmetry breaks down because volumes differ (assuming $\tau=\sigma$ ):

$$
\frac{c}{c^{*}}=\frac{x_{3}+y_{3}}{x_{3}^{\star}+y_{3}^{*}}=\frac{1}{1+\tau}
$$

where $c\left(c^{*}\right)$ is consumption volume in the home (foreign) country.

We have introduced assets that allow shifting wealth to or from a state where a border adjustment tax (by the home countries) is introduced. Households optimally choose to ensure the value of their wealth (i.e., the value of an additional unit of money) from the trade policy shock. In the standard static deterministic framework, it is only the relative price of a good that guides resource allocation and this relative price remains the same. However, in a stochastic framework with asset markets, consumers also respond to changes in the relative price of a good across states by shifting consumption from one state to another via asset markets.

\footnotetext{
$\overline{\mathrm{C} .12}$ Using $p_{0}$ as numeraire only requires $\pi_{0}>0$.
} 